\title{
State incentives to promote organ donation: honoring the principles of reciprocity and solidarity inherent in the gift relationship
}

\author{
Mélanie Levy* \\ Edmond J. Safra Center for Ethics, Buchmann Faculty of Law, Tel Aviv University, 6997801 Tel Aviv, Israel \\ Corresponding author. E-mail: melanie.a.levy@gmail.com
}

\begin{abstract}
ABST RACT
Organ transplantation saves the lives of thousands of patients worldwide every year. However, a chronic organ shortage overshadows this success. We define the organ shortage as a public health problem due to its serious consequences on patients and society. This definition raises the question of the state's role in transplantation medicine. It leads us to formulate a public policy promoting organ donation through state incentives, ie regulatory instruments to reward individuals' willingness to donate. Incentives allow the state to express gratitude for the solidary act of the donor toward the recipient and society. In an original approach, we integrate sociological findings as to the act of donation-the concept of reciprocity most importantly-into the core attributes of such a public policy. Addressing regulatory design questions, we present incentives such as allocation priority, tax benefits, health insurance discounts, and coverage of funeral costs. We also examine the unique non-financial incentive successfully implemented in Israel. We then discuss the legal and ethical framework in which state incentives have to operate, concluding that normative constraints can be addressed through law reform. Finally, we focus
\end{abstract}

\footnotetext{
* Mélanie Levy is an adjunct lecturer at the Weizmann Institute of Science (from 2017) and the Buchmann Faculty of Law at Tel Aviv University (from 2018) in Israel. She obtained her Ph.D. in Law from the University of Neuchatel (Switzerland) and her LL.M. from Cambridge University (UK). Her research interests lie at the intersection of law, medicine, technology, and society.
}

(C) The Author(s) 2018. Published by Oxford University Press on behalf of Duke University School of Law, Harvard Law School, Oxford University Press, and Stanford Law School. This is an Open Access article distributed under the terms of the Creative Commons Attribution-NonCommercial-NoDerivs licence (http://creativecommons.org/licenses/by-nc-nd/4.0/), which permits non-commercial reproduction and distribution of the work, in any medium, provided the original work is not altered or transformed in any way, and that the work is properly cited. For commercial re-use, please contact journals.permissions@oup.com 
on aspects neglected so far in public information campaigns and discuss the interaction between state policy and public opinion.

KEYW O R D S: Organ shortage, Public health, Stewardship role of the state, Reciprocity and Solidarity, State incentives, Regulatory design

\section{INTRODUCTION}

Transplantation medicine finds itself at a crossroads in terms of public policy, as today's legal frameworks for organ donation are inadequate to deal with a challenging reality. Despite the implementation of various measures over the years, the disparity between the number of organs donated and the needs of patients continues to grow throughout the developed world. ${ }^{1}$ The number of organs to treat patients on the waiting list is insufficient, and it is ever more so.

Given the serious organ shortage, there are fierce debates about a legally and ethically acceptable way of promoting organ donation. Traditional scholarship has dealt with the question of reforming current organ procurement systems along the lines dividing altruism and market-based approaches, or the gift versus market dichotomy. ${ }^{2}$

1 These measures include public awareness campaigns; education of the medical profession; optimization of hospital procedures; consent models (eg presumed consent); donor pool extension through non-heartbeating donors (ie donation after circulatory determination of death) and less-than-ideal donors (ie expanded criteria donors, due to advanced age for example). For an overview of measures and their effectiveness, see Paula Chatterjee et al., The Effect of State Policies on Organ Donation and Transplantation in the United States, 175 JAMA: Intern. Med. 1323 (2015); Matthew Dyson et al., Transplanting Suboptimum Organs: Medicolegal Implications, 386 The LANCeT 719 (2015); T. Randolph BeARd ET AL., The Global Organ Shortage - Economic Causes, Human Consequences, Policy Responses $113 \mathrm{ff}$ (2013); Alexandra K. Glazier, Systematic Increases in Organ Donation: the United States Experience, in Organ SHortage: Ethics, LAW, AND Pragmatism 195 (Anne-Maree Farrell et al. ed., 2011); David L. Kaserman, Fifty Years of Organ Transplants: the Successes and the Failures, 23 Issues L. \& MED. 45 (2007); Mark S. Nadel \& Carolina A. Nadel, Using Reciprocity to Motivate Organ Donations, 5 Yale J. Health Pol’y L. Ethics 293 (2005); Council of Europe, Meeting The Organ Shortage: Current Status And Strategies For Improvement Of Organ DonaTion - A European Consensus Document 1ff (1999); Phyllis Coleman, 'Brother, Can You Spare a Liver?' Five Ways to Increase Organ Donation, 31 VAL. U.L. REv. 1 (1996); William Dejong et al., Options for Increasing Organ Donation: The Potential Role of Financial Incentives, Standardized Hospital Procedures, and Public Education to Promote Family Discussion, 73 Milbank Q. 463 (1995); Andy H. Barnett \& David L. Kaserman, The Shortage of Organs for Transplantation: Exploring the Alternatives, 9 Issues L. \& MED. 117 (1993); Aaron Spital, The Shortage of Organs for Transplantation. Where Do We Go From Here?, 325 NEJM 1243 (1991); Howard S. Schwartz, Bioethical and Legal Considerations in Increasing the Supply of Transplantable Organs: From UAGA to 'Baby Fae', 10 Aм. J. L. Med. 397 (1985).

2 T. Randolph Beard \& Jim Leitzel, Designing a Compensated-Kidney Donation System, 77 L. \& CONTEMP. PROBS. 253 (2014); I. Glenn Cohen, Regulating the Organ Market: Normative Foundations for Market Regulation, 77 L. \& Contemp. Probs. 71 (2014); James Stacey Taylor, Public Moralities and Markets in Organs, 39 J. Med. PHILOS. 223 (2014); Chloe Sharp \& Gurch Randhawa, Altruism, Gift Giving and Reciprocity in Organ Donation: A Review of Cultural Perspectives and Challenges of the Concepts, 28 TrANSPL. REv. 163 (2014); Francis L. Delmonico et al., Proposed Standards for Incentives for Organs Donation Are Neither International nor Acceptable, 12 Am. J. Transplant. 1954 (2012); Ben Saunders, Altruism or Solidarity? The Motives for Organ Donation and Two Proposals, 26 BIoETHICs 376 (2012); Cody Corley, Money as a Motivator: The Cure to Our Nation's Organ Shortage, 11 Hous. J. Health. L. \& Pol’y 93 (2011); Nikola Biller-Andorno \& Alexander M. Capron, 'Gratuities' for Donated Organs: Ethically Indefensible, 377 The LANCET 1390 (2011); Debra SATZ, WHY SOME THINGS SHOULD NOT BE FOR SALE: THE MORAL LIMITS OF MARKETS 189ff (2010); Julia D. Mahoney, Altruism, Markets, and Organ Procurement, 72 L. \& ConTemp. Probs. 17 (2009); Jeremy R. Chapman, Should We Pay Donors to Increase the Supply of Organs for Transplantation? No, 336 BMJ 1343 (2008); Celine Fabre, Whose Body is it Anyway?: Justice And the Integrity of the Person 126ff (2006); 
Proponents of altruistic donation, on the one hand, defend the myth of donation as a selfless, altruistic act and oppose changes to the current system. Market advocates, on the other hand, see no obstacle in considering organs as tradable goods and praise the beneficial consequences of an increased number of available organs. This dichotomy has yet to be overcome.

However, there is an alternative approach to reduce the shortfall in organs: incentivized donation, ie the state offering incentives to promote individuals' willingness to donate. In a report published in 2011, ${ }^{3}$ the UK Nuffield Council on Bioethics for example claims that the state plays a role in encouraging individuals to donate their organs. Although altruism should continue to be at the heart of donation as it underpins important community values, this does not exclude the possibility of reward. The Nuffield Council states that body parts should not be 'bought' or 'sold' directly, ie exchanging money in direct return for body parts. Going beyond the gift versus market dichotomy, it considers favorably though the concept that the state rewards donors for their act and

Michele GoOdWin, Black MARKeTS: THE SUPPLY AND DEMAND OF BOdY PARTS 1ff (2006); Benjamin E. Hippen, The Case for Kidney Markets, The New Atlantis 47 (2006); Kieran J. Healy, Last BeSt gifts: altruism AND THE MARKET FOR HUMAN BLOOD AND ORGANS 1ff (2006); Raj R. Kishore, Human Organs, Scarcities, and Sale: Morality Revisited, 31 J. Med. Ethics 362 (2005); Benjamin E. Hippen, In Defense of a Regulated Market in Kidneys from Living Vendors, 30 J. MED. PHILOS. 593 (2005); MARK J. CHERry, KidNEY For SALE By OwNER: Human Organs, Transplantation, and the Market 1ff (2005); Janet Radcliffe-Richards, The Case for Allowing Kidney Sales, in ETHICAL, Legal, AND Social Issues in OrGantransPlantation 272 (Thomas Gutmann et al. ed., 2004); Francis L. Delmonico, No Payments for Organs, in ETHICAL, LeGal, AND Social Issues In Organtransplantation 294 (Thomas Gutmann et al. ed., 2004); Andrew Wancata, No Value for a Pound of Flesh: Extending Market-Inalienability of the Human Body, 18 J. L. \& HeALth 199 (2003/2004); Charles A. Erin \& John Harris, An Ethical Market in Human Organs, 29 J. Med. EтHICs 137 (2003); Gregory Boyd, Considering a Market in Human Organs, 4 N.C. J. L. \& TECH. 417 (2003); David L. Kaserman, Markets for Organs: Myths and Misconceptions, 18 J. Contemp. Health. L. \& Pol'y 567 (2002); John Harris \& Charles A. Erin, An Ethically Defensible Market in Organs, 325 BMJ 114 (2002); Ignazio R. Marino et al., Ethical Market in Organs. Market of Organs is Unethical Under Any Circumstances, 325 BMJ 835 (2002); Francis L. Delmonico et al., Ethical Incentives - Not Payment - For Organ Donation, 346 NEJM 2002 (2002); Shelby E. Robinson, Organs for Sale? An Analysis of Proposed Systems for Compensating Organ Providers, 70 U. COLO. L. REV. 1019 (1999); Thomas J. Bole, The Sale of Organs and Obligations to One's Body: Inferences from the History of Ethics, in Persons and Their Bodies: Rights, Responsibilities, Relationships 331 (Mark J. Cherry ed., 1999); A. Frank Adams et al., Markets for Organs: The Question of Supply, 17 ConTEMP. ECON. Pol'y 147 (1999); Abdallah S. Daar, Paid Organ Donation - the Grey Basket Concept, 24 J. Med. Eтнics 365 (1998); Erwin Bernat, Marketing of Human Organs?, 14 MED. \& L. 181 (1995); Gregory S. Crespi, Overcoming the Legal Obstacles to the Creation of a Futures Market in Bodily Organs, 55 OHIO ST. L. J. 1 (1994); Bernard M. Dickens, Morals and Legal Markets in Transplantable Organs, 2 HeAlth L. J. 121 (1994); Charles A. Erin \& John Harris, A Monopsonistic Market_orHow to Buy and Sell Human Organs, Tissues and Cells Ethically, in LIFE AND DEATH Under High Technology Medicine 134 (I Robinson ed., 1994); George P. Smith, Market and Non-Market Mechanisms for Procuring Human and Cadaveric Organs: When the Price is Right, 1 MED. L. INT'L 17 (1993); Andrew Kimbrell, The Human Body Shop: The Cloning, Engineering, and Marketing of Life $1 \mathrm{ff}$ (1993); Stephen J. Spurr, The Proposed Market for Human Organs, 18 J. HeAlth Pol. Pol'y L. 189 (1993); Jack Kevorkian, A Controlled Auction Market is a Practical Solution to the Shortage of Transplantable Organs, 11 MED. \& L. 47 (1992); Lloyd R. Cohen, Increasing the Supply of Transplant Organs: the Virtues of a Futures Market, 58 GeO. WASH. L. REv. 1 (1989); Henry Hansmann, The Economics and Ethics of Markets for Human Organs, 14 J. Health Pol. Pol’y L. 57 (1989); Pranlal Manga, A Commercial Market for Organs? Why Not?, 1 Bioethics 321 (1987); Margaret J. Radin, Market-Inalienability, 100 Harv. L. Rev. 1849 (1987); Richard Schwindt \& Aidan R. Vining, Proposal for a Future Delivery Market for Transplant Organs, $11 \mathrm{~J}$. HeALTH POL. POL'y L. 483 (1986); Marvin Brams, Transplantable Human Organs: Should Their Sale be Authorized by State Statutes?, 3 AM. J. L. MeD. 183 (1977).

3 Nuffield Council on Bioethics, Human Bodies: Donation For Medicine ANd Research - Report 132ff (2011). 
offers incentives as an ethical way of encouraging donation. The scholarly literature also increasingly debates incentives from the angles of medicine, law, philosophy, economy, and bioethics, although rarely from the perspective of public policy focusing on the role of the state. ${ }^{4}$

In this paper, we refer to the analytical framework of public policy to explore the organ shortage, its consequences, and state incentives as possible remedies. The paper uniquely bridges a theoretical analysis of the foundations of state intervention in organ

4 Sally L. Satel \& David C. Cronin, Time to Test Incentives to Increase Organ Donation, 175 JAMA: INTERN. MED. 1329 (2015); Daniel R. Salomon et al., AST/ASTS Workshop on Increasing Organ Donation in the United States: Creating an 'Arc of Change' From Removing Disincentives to Testing Incentives, 15 AM. J. Transplant 1173 (2015); Sally L. Satel et al., State Organ-Donation Incentives Under the National Organ Transplant Act, 77 L. \& Contemp. Probs. 217 (2014); Timothy Caulfield et al., Incentives and Organ Donation: What's (really) Legal in Canada?, 1 Can. J. Kidney Health \& Dis. 7 (2014); Ingrid Schneider, The Body, the Law, and the Market: Public Policy Implications in a Liberal State, in Human Rights And Human Nature 197 (Marion Albers et al. ed., 2014); Vardit Ravitsky, Incentives for Postmortem Organ Donation: Ethical and Cultural Considerations, 39 J. MED. EтHICs 380 (2013); Working Group on Incentives for Living Donation, Incentives for Organ Donation: Proposed Standards for an Internationally Acceptable System, 12 AM. J. Transplant 306 (2012); Thomas S. Petersen \& Kasper Lippert-Rasmussen, Ethics, Organ Donation and Tax: A Proposal, 38 J. Med. Ethics 451 (2012); Arthur J. Matas et al., A Realistic Proposal-Incentives May Increase Donation-We Need Trials Now!, 12 Am. J. Transplant 1957 (2012); Melanie Mader, Le don d’organes entre graTUITÉ ET MODÈLES DE RÉCOMPENSE: QUELS INSTRUMENTS ÉTATIQUES FACE À LA PÉNURIE D'ORGANES? 355ff (2011); Melanie Mader, Organspende zwischen Unentgeltlichkeit und Belohnungsmodellen, SCHWEIZERISCHE ZeITSCHRIFT FÜr GesundHEITSRECHT 125 (2011); Muireann Quigley, Incentivising Organ Donation, in ORgan Shortage: Ethics, LaW, and Pragmatism 89 (Anne-Maree Farrell et al. ed., 2011); Faisal Omar et al., Incentivizing Deceased Organ Donation: A Swedish Priority-Setting Perspective, 39 SCAND. J. PUBliC HeALTH 156 (2011); Linda Wright \& Diego S. Silva, Incentives for Organ Donation: Israel's Novel Approach, $375 \mathrm{THE}$ LANCET 1233 (2010); Alena M. Buyx, Anreize in der Postmortalen Organspende: Belohnte Spendebereitschaft, 21 Eтнік Med. 7 (2009); Michele Goodwin, Rethinking Federal Organ Transplantation Policy: Incentives Best Implemented by State Governements, in WHEN ALTRUISM Isn'T ENOUGH: THE CASE FOR COMPENSATING KIDNEY Donors 111 (Sally L. Satel ed., 2008); Benjamin E. Hippen \& Sally L. Satel, Crowding Out, Crowding In, and Financial Incentives for Organ Procurement, in WHEN ALTRUISM ISN'T ENOUgH: THE CASE FOR COMPENSATING Kidney Donors 96 (Sally L. Satel ed., 2008); Satel L. Satel, When Altruism Isn't Enough: The Case for Compensating Kidney Donors 1ff (2008); Gert Van Dijk \& Medard T. Hilhorst, Financial incenTIVES FOR ORGAN DONATION-AN INVESTIGATION OF THE ETHICAL ISSUES: ETHICS AND HEALTH MONITORING REPORT 1ff (2007); Gary S. Becker \& Julio J. Elias, Introducing Incentives in the Market for Live and Cadaveric Organ Donations, 21 J Econ. Perspect. 3 (2007); Arthur J. Matas, A Gift of Life Deserves Compensation-How to Increase Living Kidney Donation With Realistic Incentives, POL'Y ANAlysis 1 (2007); Patrick D. Carlson, The 2004 Organ Donation Recovery and Improvement Act: How Congress Missed an Opportunity to Say "Yes" to Financial Incentives for Organ Donation, 23 J. Contemp. Health L. \& Pol’y 136 (2006); David I. Flamholz, A Penny for Your Organs: Revising New York's Policy Offering Financial Incentives for Organ Donation, 14 J. L. \& Pol'y 329 (2006); Cindy L. Bryce et al., Do Incentives Matter? Providing Benefits to Families of Organ Donors, 5 Am. J. Transplant 2999 (2005); Steve P. Calandrillo, Cash for Kidneys? Utilizing Incentives to End America's Organ Shortage, 13 Geo. Mason. L. Rev. 69 (2004); Renate M. De Vos et al., Organ Transplants: Saving Lives: Making the Case to Test Financial Incentives to Increase the Deceased Donor Supply, in ETHICAL, LEGAL, and Social Issues in Organtransplantation 331 (Thomas Gutmann et al. ed., 2004); John B. Dossetor, Financial and Other Incentives in Post-Mortem and Living Donor Organ Transplantation-Which are Ethically

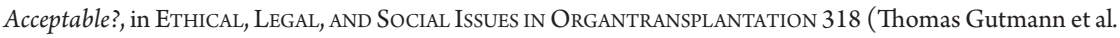
ed., 2004); Robert Arnold et al., Financial Incentives for Cadaver Organ Donation: An Ethical Reappraisal, 73 Transplantation 1361 (2002); Curtis E. Harris \& Stephen P. Alcorn, To Solve a Deadly Shortage: Economic Incentives for Human Organ Donation, 16 Issues L. \& MED. 213 (2001); William Dejong et al., supra note 1, at 463; Roger W. Evans, Organ Procurement Expenditures and the Role of Financial Incentives, 269 JAMA 3113 (1993); Andy H. Barnett \& David L. Kaserman, supra note 1, at 117; Dilip S. Kittur et al., Incentives for Organ Donation?, 338 THE LANCET 1441 (1991). 
donation with reflections on the compatibility of incentives with normative constraints such as the prohibition of organ sales.

Analysing empirical data on its causes and consequences, we define the organ shortage as a public health problem (Section II). State incentives are a successful regulatory tool in other areas of public health. We thus dissect the conceptual underpinnings and normative justifications of a public policy promoting organ donation based on incentives. Also, we integrate sociological findings as to the nature of the act of donation - the concept of reciprocity most importantly-into considerations on the core attributes of such a public policy. We argue that state incentives rewarding individuals' willingness to donate, as an expression of society's appreciation of a generous and solidary act, are more appropriate than the current system of altruistic donation (Section III). To address regulatory design questions, we present various state incentives and then focus on Israel's allocation priority for registered donors, the first incentive successfully implemented on a state level (Section IV). We also discuss legal and ethical concerns raised by incentivized organ donation. Presenting the necessary safeguards to be implemented, we define the legal and ethical framework in which a regulated system of state incentives can operate in a safe, fair, and effective manner (Sections V and VI). Finally, we focus on aspects neglected so far in public information campaigns and discuss the interaction between state policy and public opinion (Section VII).

Regulation of organ donation and transplantation remains a competence firmly attached to the realm of the nation-state. The organ shortage constitutes a recurrent phenomenon all over the developed world though. Conceptual and normative reflections on the design of public policies based on incentives are thus valid beyond the limited analysis of one state's legal framework. They may constitute the foundation for political action and regulatory change in various national contexts. This is not to say that local and cultural particularities and sensitivities, as related to the body, its parts, and death, may be ignored when designing such public policies.

\section{TRANSPLANTATION MEDICINE'S CHALLENGING REALITY}

\section{II.A. Organ shortage and its causes}

The organ shortage can be defined as a mismatch between demand and offer for organs. In the developed world, the availability of organs to treat patients in need is insufficient. The member states of Eurotransplant, for example, presented a combined waiting list of 14,773 patients in 2017, compared to 7207 organs from dead and living donors transplanted in 2017. In the USA, 114,734 patients were waiting for a new organ in March 2018, while a total of 34,771 organs from dead and living donors were transplanted in $2017 .{ }^{6}$ While the number of patients on the waiting list has steadily increased over the years, the number of organ donors has remained almost invariably low. As a consequence, there is a widening gap between these two variables defining the extent of activities in transplantation medicine.

See http://statistics.eurotransplant.org/ (accessed Mar. 14, 2018).

See https://optn.transplant.hrsa.gov/data/view-data-reports/national-data/ (accessed Mar. 14, 2018). 
The rise of patients waiting for an organ is due to various factors. First, transplantation medicine is a success story. Over the years, organ transplantation has developed from an experimental treatment into an effective medical intervention in terms of patient and graft survival. ${ }^{7}$ Patients suffering from organ failure thus demand access to this beneficial treatment option. Second, demographic changes also have an impact. ${ }^{8}$ General life expectancy is expanding, which creates a larger pool of patients needing an organ at some point in their lives. ${ }^{9}$ Third, public health factors play a significant role too, as more and more individuals suffer from modern civilization diseases. ${ }^{10}$ Unhealthy diets, physical inactivity, and excessive consumption of alcohol contribute to the growing prevalence of obesity, high blood pressure, and type 2 diabetes. These conditions may eventually lead to organ failure. Individual lifestyle and risk behavior are thus a contributory or even causal factor of the organ shortage. ${ }^{11}$

\section{II.B. Organ shortage and its consequences}

Despite the implementation of various measures over the years, the disparity between patients in need for a new organ and organs donated continues to grow in most parts of the developed world. The resulting organ shortage has many serious consequences.

The most tragic consequence is the premature death of patients on the waiting list. Waiting times from listing until transplantation continue to rise, as does list mortality. ${ }^{12}$ Eurotransplant registered 1268 patients' deaths in $2017 .{ }^{13}$ In the USA, ${ }^{14} 5441$ patients died while on the waiting list in the same year. These numbers do not include patients removed from the list because their condition deteriorates to a point at which organ transplantation is no longer an appropriate treatment option (estimated at 6364 patients in the USA in 2017).

The organ shortage also leads to impaired quality of life for waitlisted patients and their relatives. Today, about 75 percent of patients need a kidney. ${ }^{15}$ These individuals undergo dialysis several times a week for many hours. As such, dialysis has a drastic impact on the patients' professional and personal lives and affects their health condition more generally.

\footnotetext{
Jeremy R. Chapman, The Consequences of Successful Transplantation, 378 THE LANCET 1357 (2011).

NufField Council on Bioethics, supra note 3, at 100.

Sally L. Satel \& Benjamin E. Hippen, When Altruism Is Not Enough: The Worsening Organ Shortage and What It Means for the Elderly, 15 Elder L. J. 153 (2007); Richard Schwindt \& Aidan R. Vining, supra note 2, at 484.

10 Arthur J. Matas, Risks of Kidney Transplantation to a Living Donor, in When Altruism Isn't Enough: ThE CASE FOR Compensating Kidney Donors 16 (Sally L. Satel ed., 2008); Sean Arthurs, No More Circumventing the Dead: The Least-Cost Model Congress Should Adopt to Address the Abject Failure of Our National Organ Donation Regime, 73 U. CIN. L. REv. 1101, 1111 (2005); Richard Schwindt \& Aidan R. Vining, supra note 2, at 484; NuFFIELD CounCIL ON BioETHICS, supra note 3, at 189.

11 Mairi Levitt, Educating the Public to Encourage Organ Donation?, in Organ Shortage: Ethics, LAW, AND Pragmatism 63 (Anne-Maree Farrell et al. ed., 2011); Alena M. Buyx, supra note 4, at 8.

12 Thomas S. Petersen \& Kasper Lippert-Rasmussen, supra note 4, at 451; Working Group on Incentives for Living Donation, supra note 4, at 307.

13 See http://statistics.eurotransplant.org/ (accessed Mar. 14, 2018).

14 See https://optn.transplant.hrsa.gov/data/view-data-reports/national-data/ (accessed Mar. 14, 2018).

15 See http://statistics.eurotransplant.org/; https://optn.transplant.hrsa.gov/data/view-data-reports/ national-data/ (accessed Mar. 14, 2018). On the issue of the kidney shortage, see Philip J. Cook \& Kimberly D. Krawiec, A Primer on Kidney Transplantation: Anatomy of the Shortage, 77 L. \& CONTEMP. Probs. 1 (2014).
} 
A declining success rate for transplantations is another consequence of the organ shortage. ${ }^{16}$ The longer a patient remains on the waiting list, the sicker he becomes. Organ transplantation occurring a long time after listing is usually less successful in terms of patient and organ survival. For patients in need of a kidney, in particular, the duration of dialysis has an adverse impact on the success rate of subsequent kidney transplantation. $^{17}$

Furthermore, the organ shortage involves significant costs. Most patients need a kidney and rely on dialysis while waiting for a transplant. In Canada for example, hemodialysis costs about $\$ 60,000$ per patient per year compared to $\$ 23,000$ for a kidney transplantation plus $\$ 6000$ a year for lifelong medications. ${ }^{18}$ Prolonged dialysis thus entails important financial expenditures. ${ }^{19}$ Kidney transplantation is not only cheaper but also more successful in terms of patient survival. In fact, kidney transplantation is the most effective and cost-efficient treatment for end-stage renal disease. ${ }^{20}$ In addition, dialysis patients are rarely able to pursue a regular professional activity, whereas most kidney recipients regain their work capacity. The organ shortage hence also causes public spending on disability pensions for instance. ${ }^{21}$

Finally, the organ shortage gives rise transplant tourism and organ trafficking. ${ }^{22}$ Patients from developed countries-unable or unwilling to wait-travel to developing countries to buy kidneys on the black market. The poor and vulnerable local 'donors' are offered a sum they cannot refuse, but often do not receive the promised financial compensation, and usually remain without proper medical

16 Arthur J. Matas, supra note 10, at 16 ff; Sally L. Satel, Introduction, in WHEN Altruism Isn't EnOUgh: THE CASE For Compensating Kidney Donors 5 (Sally L. Satel ed., 2008); Gary S. Becker \& Julio J. Elias, supra note 4, at 15; Friedrich Breyer eT AL., OrganMangel: IST DER TOD AUf DER WARTEliste UNVERMEIDBAR? 17 (2006).

17 Ideally, patients with kidney failure should receive a transplant rather than start dialysis ('preemptive transplantation'), to avoid the negative consequences of dialysis: Sally L. Satel \& David C. Cronin, supra note 4, at 1329.

18 Canadian Institute for Health Information, Canadian Organ Replacement Register Annual RePORT: Treatment of END-STAge ORgan Failure IN CANADA 2001 to $20101 \mathrm{ff}$ (2012). These numbers are comparable to other developed countries. See Melanie Mader, supra note 4, at 17; GERT VAN DIJK \& MEDARD T. HilHORST, supra note 4, at 33.

19 Depending on the type of health care system, these costs are paid by the state, social health insurers (sickness funds), private insurance companies, or even individual patients.

20 Philip J. Held et al., A Cost-Benefit Analysis of Government Compensation of Kidney Donors, 16 AM. J. TRANSPLANT. 877 (2016); Jeremy R. Chapman, supra note 7, at 1357.

21 If disability pensions are not covered through a public social security system, they may be taken care of by private insurance. In that case, prolonged dialysis increases expenditures for private insurance companies.

22 I. Glenn Cohen, Patients with Passports - Medical Tourism, LaW, and Ethics 263ff (2014); I. Glenn Cohen, Transplant Tourism: The Ethics and Regulation of International Markets for Organs, 41 J. L. MED. ETHICS 269 (2013); Alireza Bagheri \& Francis L. Delmonico, Global Initiatives to Tackle Organ Trafficking and Transplant Tourism, 16 Med. Health Care Philos. 887 (2013); Benita Padilla et al., Impact of Legal Measures Prevent Transplant Tourism: The Interrelated Experience of The Philippines and Israel, 16 MED. HEALTH CARE PHiLOS. 915 (2013); Asif Efrat, Combating The Kidney Commerce - Civil Society Against Organ Trafficking in Pakistan and Israel, 53 BR. J. CRIMINOL. 764 (2013); Asif Efrat, The Rise and Decline of Israel's Participation in the Global Organ Trade: Causes and Lessons, 60 Crime L. Soc. Change 81 (2013); Council of Europe \& United Nations, Trafficking In Organs, Tissues And Cells And Trafficking In Human Beings For The Purpose Of The Removal Of Organs 53ff (2009); Nancy Scheper-Hughes, Organs Without Borders, Foreign Policy 26 (2005); Nancy Scheper-Hughes, Keeping an Eye on the Global Traffic in Human Organs, 361 The LANCET 1645 (2003); Nancy Scheper-Hughes, The Global Traffic in Human Organs, 41 CuRR. ANTHROPOL. 191 (2000). 
follow-up. ${ }^{23}$ Some US health insurers even offer a transplantation vacation abroad. ${ }^{24}$ These companies pay for the flight, the medical procedure, the organ, and all related costs because such a 'vacation' is cheaper than bearing the costs of prolonged dialysis. ${ }^{25}$ Health insurers justify their support of transplant tourism with cost-efficiency and cost-savings while ignoring the situation of the local organ 'donor'. ${ }^{26}$ The fact that some patients return from their trip abroad with post-transplantation complications (eg substandard surgery, infections, transmissible diseases) adds to this problematic situation. The costs of care for these patients are significant and probably contradict expectations of financial savings. ${ }^{27}$

\section{STEWARDSHIP ROLE OF THE STATE}

\section{III.A. Public interests at stake}

Considering its serious consequences on patients and society, the organ shortage can be defined as a public health problem or a 'critical public health challenge'. ${ }^{28}$ This definition opens up the question of the state's responsibility in transplantation medicine. ${ }^{29}$

Saving human lives and improving the quality of life of patients waiting for an organ represent critical public interests. ${ }^{30}$ The literature also refers to compelling state interests in response to health needs. ${ }^{31}$ Beyond the language of interests, safeguarding lives

23 Alireza Bagheri \& Francis L. Delmonico, supra note 22, at 888; Benita Padilla et al., supra note 22, at 919; Asif Efrat, supra note 22, at 81; Tamar Ashkenazi et al., Effect of a Legal Initiative on Deceased-and Living-Donor Kidney Transplantation in Israel, 45 Transplant Proc. 1301 (2013); Council of Europe \& United Nations, supra note 22, at 53ff; Madhav Goyal et al., Economic and Health Consequences of Selling a Kidney in India, 288 JAMA 1589 (2002).

24 Katrina A. Bramstedt \& Jun Xu, Checklist: Passport, Plane Ticket, Organ Transplant, 7 Am. J. Transplant 1698 (2007).

25 This phenomenon also occurred in Israel before the adoption of the new Organ Transplantation Law in 2008. Up until 2008, Israeli insurance companies and sick funds reimbursed transplantation operations performed abroad, regardless of the origin of the donor or the legality of the operations according to national laws. The new law declares organ trade and trafficking illegal and bans the reimbursement of organ transplantations performed abroad. See Jacob Lavee et al., Preliminary Marked Increase in the National Organ Donation Rate in Israel Following Implementation of a New Organ Transplantation Law, 13 AM. J. TRANSPLANT 780 (2013); Benita Padilla et al., supra note 22, at 916; Asif Efrat, The Politics of Combating the Organ Trade: Lessons From the Israeli and Pakistani Experience, 13 Am. J. Transplant 1650 (2013); Asif Efrat, supra note 22, at 776; Asif Efrat, supra note 22, at 83ff; Tamar Ashkenazi et al., supra note 23, at 1301.

26 Jacob Lavee et al., supra note 25, at 780; Asif Efrat, supra note 22, at 775; Asif Efrat, supra note 22, at 83 and $86 \mathrm{ff}$. One may add here that public payers like Medicare cover immunosuppressive drugs for patients who acquired an organ through transplant tourism, and as such offer indirect state support for this phenomenon.

27 Tamar Ashkenazi et al., supra note 23, at 1301; Ashley E. Anker \& Thomas H. Feeley, Estimating the Risks of Acquiring a Kidney Abroad: A Meta-Analysis of Complications Following Participation in Transplant Tourism, 26 CLIN. TRANSPL. E232 (2012); Jeremy R. Chapman, supra note 7, at 1357.

28 Paula Chatterjee et al., supra note 1, at 1323. See also Melanie Mader, supra note 4, at 397ff; Howard K. Koh et al., A Statewide Public Health Approach to Improving Organ Donation: The Massachusetts Organ Donation Initiative, 97 Am. J. Pub. Health 30, 30 (2007); Sophia Wille, Sozialpflicht zur Organspende?, in AnReIZE ZUR ORGANSPENDE 7 (Friedrich Breyer \& Margret Engelhard ed., 2006); Patrick D. Carlson, supra note 4, at 138. Blumstein has debated this question within the US organ procurement system, focusing on the federal government's involvement and its relation to the United Network for Organ Sharing: James F. Blumstein, Government's Role in Organ Transplantation Policy, 14 J. Health Pol. Pol’y L. 5 (1989).

30 We have discussed this point in detail elsewhere; see Melanie Mader, supra note 4, at 397ff.

31 Jonathan G. August, Modern Models of Organ Donation: Challenging Increases of Federal Power to Save Lives, 40 Hastings Const. L. Q. 393, 409 (2013); Patrick D. Carlson, supra note 4, at 155; Nuffield Council on Bioethics, Human Bodies: Donation for Medicine and Research - A Guide to the Report 12 (2011). 
can also be regarded as the central dogma of the constitutionally regulated state: 'the first duty of any state committed to the rule of law is to take responsibility for its people's lives' 32

The range of public interests at stake goes beyond addressing individual health needs tough. There is a public interest in improved donation rates to alleviate dependence on dialysis and lessen the cost burden on health care systems. ${ }^{33}$ Also, many transplant recipients can re-enter the workforce, thus reducing costs for social security systems. ${ }^{34} \mathrm{Fi}$ nally, the fight against transplant tourism and organ trafficking also constitutes a public interest. $^{35}$

Based on these important public interests, the state assumes multiple roles in transplantation medicine. The organ shortage is not a natural and unchangeable matter of fact. The role of the state can therefore hardly be limited to regulating and controlling organ quality, safety, and just allocation of organs. It is indeed also part of the state's role to encourage donation and increase the number of available organs. ${ }^{36}$ The state plays an essential role with regard to the availability of organs for transplantation. ${ }^{37}$

In its report, the Nuffield Council describes the role of the state as a one of 'stewardship': the 'concept of the state as steward of public health is equally applicable to the responsibilities of states with respect to the donation of bodily materials' ${ }^{38}$ and 'the state has a stewardship role in maximising the donation of bodily materials, where these have the potential to contribute to improved health'. ${ }^{39}$ Being a steward implies that the state has a duty to take action, including promoting donation. This stewardship role is reflected in the legal framework of the Council of Europe's Additional Protocol to the Convention on Human Rights and Biomedicine concerning Transplantation of Organs and Tissues of Human Origin (hereafter: Additional Protocol on Transplantation). ${ }^{40}$ Article 19 enacts a legally binding international obligation for states to take 'all appropriate measures to promote the donation of organs'. It implies that states have a

32 Sheila Jasanoff, Introduction: Rewriting Life, Reframing Rights, in REFRAMING RIGHTS - BIOCONSTITUTIONALISM IN THE Genetic Age 3 (Sheila Jasanoff ed., 2011). See also Jack Michael Beermann, NFIB v. Sebelius and the Right to Health Care: Government's Obligation to Provide for the Health, Safety and Welfare of Its Citizens, 18 NYU J. Legis. \& Pub. Pol'y 277 (2015).

33 Philip J. Held et al., supra note 20, at 877; Thomas S. Petersen \& Kasper Lippert-Rasmussen, supra note 4, at 456; Faisal Omar et al., supra note 4, at 156; Elbert S. Huang et al., The Cost-Effectiveness of Renal Transplantation, in When Altruism Isn't Enough: The Case for Compensating Kidney Donors 20 (Sally L. Satel ed., 2008).

34 Philip J. Held et al., supra note 20, at 877; Asif Efrat, supra note 22, at 88; Sally L. Satel, supra note 16, at 1ff; FRIEDRICH BREYER ET AL., supra note 16, at 129.

35 The Committee of Ministers of the Council of Europe has recognized this vital public interest by adopting the Convention against Trafficking in Human Organs (ETS n ${ }^{\circ} 216$ ) on July 9, 2014.

36 Mark Schweda \& Silke Schicktanz, Shifting Responsibilities of Giving and Taking Organs? Ethical Considerations of the Public Discourse on Organ Donation and Organ Trade, in The Body As GIFT, RESOURCE, AND COMMODITY - Exchanging Organs, Tissues, And Cells in the 21St Century 255 (Martin Gunnarson \& Fredrik Svenaeus ed., 2012).

37 Promotion of organ donation is necessary, not only because the organ shortage is a public health problem, but also to protect and realize human rights such as the right to life and health of patients. For an analysis of the link between the availability of organs and human rights, see Melanie Mader, supra note 4, at 444ff.

38 NufField COUNCIL ON BIOETHICS, supra note 3, at 192.

39 Id. at 197.

40 Council of Europe, Additional Protocol to the Convention on Human Rights and Biomedicine concerning Transplantation of Organs and Tissues of Human Origin, Jan. 24, 2002, ETS n ${ }^{\circ} 186$. 
responsibility to ensure organ availability and establish a legal framework offering favorable conditions for increasing the number of organ donors. ${ }^{41}$

\section{III.B. Public policies to promote organ donation}

In contrast to previous challenges, such as transplant rejection and the development of immunosuppressive drugs, the organ shortage is a public health problem that cannot be solved by medical and technological innovation within a reasonable timeframe. It is a problem that needs to be addressed through public policy and modified regulatory frameworks.

In public health, the state applies three types of public policy instruments to obtain a change in behavior within its population. ${ }^{42}$ First, the state can impose a change in behavior by law (regulation; eg obligation to wear a seatbelt or a motorcycle helmet). Second, the state can suggest a change in behavior using information (persuasion; eg public awareness campaigns). Third, the state can induce a behavioral change through positive or negative financial incentives (incitation; eg subsidies, tax breaks, duties).

For organ donation, states currently mainly use the first and second categories of public policy instruments. An important element of state action relates to the hospital setting. The detection of potential organ donors through standardized hospital procedures is decisive. ${ }^{43}$ Many states have introduced measures via regulation, such as imposing a transplant coordinator in hospital intensive care units, assigning a physician the role of detecting potential organ donors or establishing specific protocols for brain death determination. ${ }^{44}$

Another category of state action is information through public awareness campaigns. ${ }^{45}$ Public education is an aspect that is already implemented today to various degrees in different states. ${ }^{46}$ However, public awareness campaigns have not been particularly successful in increasing organ donation rates, albeit significant budgets invested over the years. $^{47}$

41 Council of Europe, Explanatory Report: Additional Protocol to the Convention on Human Rights and Biomedicine concerning Transplantation of Organs and Tissues of Human Origin, par. 105.

42 Lawrence O. Gostin, Public Health Law - Power, Duty, Restraint 28ff (2008). We do not discuss here the recent literature on choice architecture. Based on behavioral research and economics, scholars analyse the role of nudges such as default settings in state policies aimed at influencing the decisions that its residents make, regarding their health for example. In the specific context of organ donation, see Kyle Powys Whyte et al., Nudge, Nudge or Shove, Shove - The Right Way for Nudges to Increase the Supply of Donated Cadaver Organs, 12 Aм. J. Bioeth. 32 (2012).

43 David Rodríguez-Arias et al., Success Factors and Ethical Challenges of the Spanish Model of Organ Donation, 376 THE LANCET 1109, 1109ff (2010); FRIEDRICH BREYER ET AL., supra note 16, at 65.

44 David Rodríguez-Arias et al., supra note 43, at 1109ff; William Dejong et al., supra note 1, at 470ff.

45 Mairi Levitt, supra note 11, at 52ff; Melanie A. Wakefield et al., Use of Mass Media Campaigns to Change Health Behaviour, 376 THE LANCET 1261 (2010).

46 Public authorities usually undertake some form of public education to promote individuals' willingness to donate. See British Medical Association, Building On Progress: Where NeXt For Organ Donation Policy In The UK? 42 (2012); Mark S. Nadel \& Carolina A. Nadel, supra note 1, at 303. An exception here is Switzerland, whose organ donation rates are at the lower end of the spectrum in Europe. The Swiss government has adopted a principle of neutrality, not only in international politics but also for organ donation. It plays no active role in encouraging the population to express consent to donation. A neutral position of the state is problematic though, considering the important public interests at stake. See Melanie Mader, Une Neutralité qui n'a Plus de Raison d'Etre, Bioethica Forum 74 (2010).

47 Mairi Levitt, supra note 11, at 52ff; Mark S. Nadel \& Carolina A. Nadel, supra note 1, at 304; T. Randolph Beard et al., Limits to Altruism: Organ Supply and Educational Expenditures, 22 CONTEMP. ECON. POL'y 433, 
Although information is a crucial tool in public health, it is rarely used on its own. Here an analogy to other public health problems, such as alcohol and tobacco consumption, or unhealthy lifestyles and nutrition, is revealing. In these areas, states take action to promote desirable behavior. This action includes public health campaigns (eg slogans such as 'Drink less!', 'Don't smoke!', 'Exercise more!', 'Eat healthier!') and information about poor health outcomes. However, this information is always backed up by other measures designed to encourage desirable behavior, in particular, incentives such as taxes perceived on alcohol and tobacco sales, or consumption of unhealthy foods and drinks ('fat tax'; 'sugar tax'). ${ }^{48}$

This opens up a third category of state action: promoting individuals' willingness to donate through incentives. Incentives are a common regulatory tool in various areas of social policy, particularly in public health. So far, policy makers have not seriously considered using incentives to address the organ shortage, however. We argue here that beyond the measures already in place, a public policy based on incentives is a most promising way forward.

\section{III.C. State incentives to honor the principles of reciprocity and solidarity}

State incentives are regulatory instruments to promote and reward organ donation in the context of a public policy. The purpose of incentives is to stimulate individuals' willingness to donate organs. ${ }^{49}$ We discuss here the core attributes of such a novel public policy.

Public surveys in the developed world reveal high public support for organ donation, as most individuals manifest a positive attitude toward donation. ${ }^{50}$ The medical reality has been different though, characterized by high abstention and refusal rates. ${ }^{51}$ The predominantly positive attitude only leads to few expressions of consent by the donor while alive or his relatives after death. The literature describes this phenomenon as an attitude/action gap. ${ }^{52}$ State incentives address this gap. They provide the necessary impetus to overcome individuals' laziness, apathy, inertia, or other barriers in

433ff(2004). On the role of new online and social media to promote organ donation, see Andrew M. Cameron et al., Social Media and Organ Donor Registration: The Facebook Effect, 13 AM. J. Transplant 2059 (2013); Michael Stefanone et al., Click to "Like" Organ Donation: the Use of Online Media to Promote Organ Donor Registration, 22 Prog. Transplant 168 (2012).

48 LAWRENCE O. Gostin, supra note 42, at 28ff; Melanie Mader, supra note 4, at 428.

49 Committee on Increasing Rates of Organ Donation, Organ donation: Opportunities For action 229 (2006). Incentives to promote organ donation operate in a system of explicit consent ('opt-in'). Such a system implies that potential donors have to take a proactive step to express their consent. The literature has compared the effects of consent default settings in organ donation systems. Presumed consent alone is unlikely to explain the variation in organ donation rates between countries. See Amber Rithalia et al., Impact of Presumed Consent for Organ Donation on Donation Rates: A Systematic Review, 338 BMJ 284 (2009); Hendrik P. Van Dalen \& Kène Henkens, Comparing the Effects of Defaults in Organ Donation Systems, 106 SoC. SCI. MED. 137 (2014).

50 Margaret Brazier \& John Harris, Does Ethical Controversy Cost Lives?, in Organ SHORTAGE: ETHICS, LAW, AND Pragmatism 20 (Anne-Maree Farrell et al. ed., 2011). For the UK, see Mairi Levitt, supra note 11, at 52ff. For the USA, see Andrew M. Cameron et al., supra note 47, at 2061. For Canada, see Jennifer A. Chandler, Priority Systems in the Allocation of Organs for Transplant: Should We Reward Those Who Have Previously Agreed to Donate?, 13 Health L. J. 99, 105 (2005).

51 Andrew M. Cameron et al., supra note 47, at 2061; Thomas S. Petersen \& Kasper Lippert-Rasmussen, supra note 4, at 451; Mairi Levitt, supra note 11, at 52ff; Jennifer A. Chandler, supra note 50, at 105ff.

52 Mairi Levitt, supra note 11, at 55; Alena M. Buyx, supra note 4, at 11; Elias Mossialos et al., Does Organ Donation Legislation Affect Individuals' Willingness to Donate Their Own or Their Relative's Organs? Evidence From 
expressing consent. ${ }^{53}$ Incentives thus act as a stimulus for the numerous individuals who are inclined to donate but have not taken action yet. ${ }^{54}$ As such, they have significant potential to alleviate the organ shortage. ${ }^{55}$

Organ donation is a generous act of solidarity of the donor or his relatives in favor of the recipient and society. ${ }^{56}$ Through incentives, the state can demonstrate appreciation and gratitude for this act. Arnold et al. note that 'the benefit (...) for donation should be perceived as an expression of gratitude on behalf of society for the gift'. ${ }^{57}$ This perception of gratitude is decisive in the context of incentives for organ donation. Incentives also allow the state to value the act of donation and publicly acknowledge this praiseworthy act. ${ }^{58}$ Furthermore, by communicating a message of appreciation and gratitude for a generous and solidary act, incentives speak to potential organ donors and their relatives not only through a rational and utilitarian channel but also include an emotionbased component. ${ }^{59}$

Incentives also take into account the concept of reciprocity, ie giving and receiving. Donation is commonly seen as a selfless act of altruism. From a sociological point of view, however, this popular image is not entirely accurate. ${ }^{60}$ According to the research

European Union Survey Data, 8 BMC Health Serv. Res. 1, 3 (2008); Gil Siegal \& Richard J. Bonnie, Closing the Organ Gap: A Reciprocity-Based Social Contract Approach, 34 J. L. MED. ETHICS 415, 419 (2006); Mark S. Nadel \& Carolina A. Nadel, supra note 1, at 295; Jennifer A. Chandler, supra note 50, at 105ff. The literature offers different explanations for this attitude/action gap. See Alena M. Buyx, supra note 4, at 11; GERT VAN DijK \& Medard T. HilHorsT, supra note 4, at 20; Gregory S. Crespi, supra note 2, at 5; Richard Schwindt \& Aidan R. Vining, supra note 2, at 486.

53 British Medical Association, supra note 46, at 63; Thomas S. Petersen \& Kasper Lippert-Rasmussen, supra note 4, at 452; Muireann Quigley, supra note 4, at 89ff; Jennifer A. Chandler, supra note 50, at 109.

54 Lianne Barnieh et al., Attitudes Toward Strategies to Increase Organ Donation: Views of the General Public and Health Professionals, 7 Clin. J. Am. Soc. Nephrol. 1956, 1961 (2012); Nurit Guttman et al., Laypeople's Ethical Concerns About a New Israeli Organ Transplantation Prioritization Policy Aimed to Encourage Organ Donor Registration Among the Public, 36 J. Health Pol. Pol’y L. 691, 707 (2011).

55 Thomas S. Petersen \& Kasper Lippert-Rasmussen, supra note 4, at 453; Working Group on Incentives for Living Donation, supra note 4, at 306ff; Alena M. Buyx, supra note 4, at 11; GERT VAN DijK \& MEDARD T. HilHorst, supra note 4, at 22; Ellen Sheehy et al., Estimating the Number of Potential Organs Donors in the United States, 349 NEJM 667, 671 (2003).

56 British Medical Association, supra note 46, at 63; Thomas S. Petersen \& Kasper Lippert-Rasmussen, supra note 4, at 453; Melanie Mader, supra note 4, at 487; Muireann Quigley, supra note 4, at 89ff; Elyse Skura, Proposed Tax Credit for Organ Donation Raises Ethical Concerns, 182 CMAJ 461, 461 (2010); GERT VAN DijK \& Medard T. Hilhorst, supra note 4, at 16; Diana Aurenque, Why Altruism is not a Convincing Argument for Promoting Post-mortem Organ Donation: Responsibility and Solidarity as Key Concepts, in ORGAN Transplantation in Times of Donor Shortage - Challenges and Solutions 61ff (Ralf Jox et al. ed., 2015).

57 Robert Arnold et al., supra note 4, at 1365.

58 Beard et al. argue for a 'donor as hero' paradigm: '(a)s part of the recognition of a heroic act, monetary compensation allows society to validate the donor's decision in a meaningful way': T. Randolph Beard \& Jim Leitzel, supra note 2, at 287. See also Melanie Mader, supra note 4, at 389; GERT VAN DiJK \& MEDARD T. HilHorst, supra note 4, at 16.

59 Cognitive-based factors (eg knowledge about organ donation) might be less influential on the decision to donate than non-cognitive variables (eg the desire to maintain bodily integrity or medical mistrust). See Susan E. Morgan et al., Facts versus 'Feelings': How Rational Is the Decision to Become an Organ Donor?, 13 J. HeALTH PSYCHOL. 644 (2008).

60 Kristin Zeiler, Neither Property Right nor Heroic Gift, Neither Sacrifice nor Aporia: the Benefit of the Theoretical Lens of Sharing in Donation Ethics, 17 Med. Health Care Philos 171, 171ff (2014); Marcel Mauss, Essai SUR LE DON: FORME ET RAISON DE L'ÉCHANGE DANS LES SOCIÉTÉS ARCHAÏQUES (AVEC UNE PRÉSENTATION DE Florence Weber) 64 (2012; originally published in 'Année Sociologique' 1923-1924); Philippe SteIner, 
of Mauss first published in 1923-1924, the gift relationship implies a circle of giving, receiving, and reciprocating. ${ }^{61}$ Reciprocity is thus a key element of the 'Maussian gift exchange theory'. Subsequent literature also notes that reciprocity is inherent in the act of donation, which is neither unidirectional nor one-sided. ${ }^{62}$ Schweda \& Schicktanz, for example, refer to the social nature of organ donation as a reciprocal social interaction between different parties. $^{63}$

Since they conceive donation as a unidirectional act, current organ procurement systems do not sufficiently take into account the symbolic meaning of the act of donation and its relational dimension. The disconnection from essential attributes of the act of donation and the gift relationship seems even more problematic considering that the gift involved here is a gift of life, which has its own significant meaning. ${ }^{64}$ Fox \& Swazey describe in fact a potential tyranny of the gift, as the recipient of the gift of life is not in a position to express his gratitude and give something back. ${ }^{65}$ By employing incentives to promote organ donation, the state can re-equilibrate the gift relationship. ${ }^{66}$

In addition, the literature acknowledges that various motives underlie the act of organ donation. ${ }^{67}$ As Schweda \& Schicktanz note: 'the strict dichotomy between the idea of purely altruistic donation and market-oriented models underlying much of the

LA TRANSPLANTATION D'ORGANES: UN COMMERCE NOUVEAU ENTRE LES ETRES HUMAINS 89ff (2010); Philippe Steiner, Le don d'organes: une typologie analytique, ReVUe FRANCAISE DE SOCIOLOGIE 479, 480 (2006); John B. Dossetor, supra note 4, at 318ff; CorinNa IrIS SCHUTZeichel, GeSCHENK ODER WARE? DAS BEgEhrTE Gut Organ: Nierentransplantation in einem hochregulierten Markt 93ff (2002); Renee C. Fox \& Judith P. Swazey, Spare Parts: Organ Replacement in American Society 31ff (1992). For a review of cultural perspectives on altruism, the gift relationship, andperceptions of the body and death, see Chloe Sharp \& Gurch Randhawa, supra note 2, at $163 \mathrm{ff}$.

61 MarCel Mauss, supra note 60, at 73ff. See also Chloe Sharp \& Gurch Randhawa, supra note 2, at 165; RENEE C. Fox \& JUdith P. SWAZEY, THE COURAGE TO FAIL: A SOCIAL VIEW OF ORGAN TRANSPLANTS AND DIALYSIS 39 (1974).

62 Mark Schweda \& Silke Schicktanz, Why Public Moralities Matter - The Relevance of Socioempirical Premises for the Ethical Debate on Organ Markets, 39 J. MED. PHILOs 217, 220 (2014); Kristin Zeiler, supra note 60, at 171ff; Mark Schweda \& Silke Schicktanz, Public Ideas and Values Concerning the Commercialization of Organ Donation in Four European Countries, 68 Soc. SCI. MED. 1129, 1134 (2009); Paolo Becchi, Ist eine Ethisch und Rechtlich Tragbare Förderung von Organspenden denkbar?, in DiE ZUKUNFT DER TRANSPLANTATION VON Zellen, Geweben und Organen 147 (Paolo Becchi et al. ed., 2007); Norbert W. Paul, Lebendorganspende als Selbstloser Akt? Anmerkungen zur Begrenzten Reichweite des Altruismus, in ANREIZE ZUR ORGANSPENDE 85 (Friedrich Breyer \& Margret Engelhard eds., 2006).

63 Mark Schweda \& Silke Schicktanz, supra note 62, at 220.

64 Chloe Sharp \& Gurch Randhawa, supra note 2, at 163ff. Organ donation creates a debt. See Jacques T. Godbout, Le don, la dette et l'identité dans le don d'organes, in LA TRANSPLANTATION D'ORGANES - ENJEUX ET PARADOXES 62 (Sylvaine De Plaen ed., 2006). Kristin Zeiler, supra note 60, at 171ff. SCHWEDA \& SCHICKTANZ describe a 'sense of indebtedness'. See Mark Schweda \& Silke Schicktanz, supra note 62, at 220.

Renee C. Fox \& Judith P. Swazey, supra note 61, at 333.

66 Chloe Sharp \& Gurch Randhawa, supra note 2, at 167. '(P)ossible ways of taking this significance of reciprocity into account could be sociocultural rituals of expressing gratitude; of public recognition of the donors' act and also a more pronounced discussion of the role of reciprocity for allocation rules': Mark Schweda \& Silke Schicktanz, supra note 62, at 220.

67 Michelle J. Irving et al., What Factors Influence People's Decisions to Register for Organ Donation? The Results of a Nominal Group Study, 27 Transpl. INT. 617, 617ff (2014); Adnan Sharif, Championing Self-Interest to Overcome Disinterest - Lessons From the Israeli Organ Allocation System, 13 AM. J. TransPlant 1611, 1611 (2013); Working Group on Incentives for Living Donation, supra note 4, at 307; Ben Saunders, supra note 2, at 378; Muireann Quigley, supra note 4, at 89ff; GerT VAN DijK \& MEDARD T. Hilhorst, supra note 4, at 30; David Price, Legal and Ethical Aspects of Organ Transplantation 397 (2000). 
academic debate does not reflect the perceptions and conflicts of the affected persons' ${ }^{68}$ Co-existence of altruistic intent and interest seems possible, or even conceptually inherent in the act of donation. A donor is rarely motivated by altruism alone. Altruism 'is one element of a donor's behavior, but the donation transcends altruism'. ${ }^{6}$ Well-conceived state incentives reflect the mixed motives underlying organ donation. They encourage altruism while offering a rewarding gesture of appreciation and gratitude. ${ }^{70}$ A system in which motivation to donate is based on altruism and interest is more coherent with regard to the conceptual and symbolic characteristics of the act of donation. Petersen \& Lippert-Rasmussen note that 'tax credits can themselves be interpreted as gifts - from the state to individuals who have done something for the common good'; thus, 'tax credits may serve to increase the number of gift relations in society. $^{71}$

Finally, a public policy based on incentives enforces the prohibition of private commercial transactions involving money and organs. A government-regulated system sets barriers to prevent abuse, by (a) limiting incentives to residents and (b) maintaining current allocation practices, ie organs are allocated to the first patient on the waiting list, and not according to individual capacity or willingness to pay. ${ }^{72}$ It follows that incentivized organ donation does not raise distributive concerns as to the allocation of organs.

State incentives depart from current practices of altruism-based donation. The altruistic system has reached its limits though. State incentives also distinguish themselves from an organ market. As Sten notes, 'such incentives do not permit the buying or selling of organs as property, but instead appear as alternatives to altruism in rewarding the decision to consent to organ donation'. ${ }^{73}$ Considering the serious organ shortage, we have to conceive organ donation beyond the altruism/market dichotomy. There is a third way, reflecting the concept of incentivized donation; the reward being offered by the state as part of a public policy. ${ }^{74}$ Based on regulation and transparency, such a public policy strives for the highest level of safety, fairness, and equality, and thus offers the necessary donor and recipient protection. ${ }^{75}$

Sally L. Satel, Concerns About Human Dignity and Commodification, in WhEn Altruism Isn'T EnOUgh: ThE Case for Compensating Kidney Donors 69 (Sally L. Satel ed., 2008); Gert VAn Dijk \& Medard T. HiLHORST, supra note 4, at 30ff; DAVID PRICE, supra note 67, at 397.

Thomas S. Petersen \& Kasper Lippert-Rasmussen, supra note 4, at 454.

We present other necessary safeguards of a regulatory system of state incentives in section V.

John A. Sten, Rethinking the National Organ Transplant Program: When Push Comes to Shove, $11 \mathrm{~J}$. ConTEMP. HeAlth L. \& Pol’y 197, 214 (1994).

To the best of our knowledge, the term 'rewarded gifting' was first coined by DAAR in 1991, see Abdallah S. Daar, Rewarded Gifting and Rampant Commercialism in Perspective: Is There a Difference?, in ORGAN REPLACEment Therapy: Ethics, Justice, Commerce 181 (Walter Land \& John B. Dossetor ed., 1991).

75 A government-regulated system of incentivized organ donation 'can, and should, operate with the highest level of transparency, where the criteria for donor qualification, levels of compensation, and the algorithms used to distribute organs are all widely accessible': T. Randolph Beard \& Jim Leitzel, supra note 2, at 279. 


\section{STATE INCENTIVES TO PROMOTE ORGAN DONATION: THE REGULATORY DESIGN}

\section{IV.A. General remarks}

This section offers an overview of incentives rewarding consent to organ donation, their regulatory design, and examples of implementation in national settings. It is deliberately succinct as a lot has been written on this topic, although rarely from a public policy perspective. ${ }^{76}$ Although one may be skeptical about the moral or theoretical relevance of the distinction, we only refer here to the introduction of incentives, and not the removal of disincentives, which is also discussed in the literature and already realized in many legal frameworks regulating organ donation. ${ }^{77}$ Before presenting various incentives, a few introductory remarks are necessary as to the type of donation, addressees of incentives, and type of incentives involved.

Incentives for living donation are different from incentives for post mortem donation. The former focuses on the donor. For the latter, we distinguish between incentives for registration as a potential donor while alive (ex ante incentives), and incentives for actual consent to organ donation by relatives after a potential donor's death (ex post incentives).

There are three types of incentives: non-financial, indirect financial, and direct financial. Non-financial incentives relate to a patient's position on the waiting list. ${ }^{78}$ They grant a certain priority on the waiting list to patients based on their previously expressed willingness to donate their organs. Indirect financial incentives provide a symbolic reward, possibly spread over time, for the gesture of donation. ${ }^{79}$ Direct financial incentives offer a purchase price for an organ on the basis of a legally binding sales contract. Whereas non-financial and indirect financial incentives are a more recent phenomenon in scholarly discussions, market ideas circulate in the literature since as early as $1977 .{ }^{80}$

\section{IV.B Non-financial incentives}

Allocation priority for registered donors and living donors are 'non-financial incentives' ${ }^{81}$

76 See note 4.

77 Daniel R. Salomon et al., supra note 4, at 1173ff. By removal of disincentives, we refer to covering expenses occurred to living donors. These expenses include travel costs to transplantation centers for donor evaluation, lost wages, childcare, and household help during post-donation recovery. Another aspect of removing disincentives for living donors is offering life and disability insurance linked to the act of donation.

78 The literature also discusses non-financial tools such as offering a 'gift of life' medal to donors or their relatives, organizing donor recognition events, etc. See for example Timothy Caulfield et al., supra note 4, at 7; Sean Arthurs, supra note 10, at 1119. Although valuing and acknowledging the act of donation, we doubt the incentivizing effect of such tools. Louis J. Sirico Jr, Donating and Procuring Organs: An Annotated Bibliography, 104 L. LiBR. J. 285, 297 (2012); Alena M. Buyx, supra note 4, at 10; David I. Flamholz, supra note 4, at 354.

80 See note 2.

81 Another non-financial incentive is pool-cross-over transplantation, also called 'list donation', 'list pair exchange', or 'paired organ exchange'. Here two donor and recipient pairs switch kidneys so as to overcome their biological incompatibility. 'Domino chains' involve multiple incompatible donor and recipient pairs. See Francis L. Delmonico et al., Donor Kidney Exchanges, 4 AM. J. Transplant 1628 (2004); Michael T. Morley, Increasing the Supply of Organs for Transplantation Through Paired Organ Exchanges, 21 YALE L. \& POL'Y REV. 221 (2003). 
'Allocation priority for registered donors' offers priority status on the waiting list should a registered potential donor ever succumb to disease and need an organ transplant himself. ${ }^{82}$ Allocation priority thus gives preference to individuals on the waiting list who have earlier expressed their consent to donate their organs after death. Here the incentive consists of quicker access to an organ in case of need. The literature uses different terminologies to describe allocation priority, such as 'preferred status' or 'solidarity model'. 83

Allocation priority for registered donors operates under a system of reciprocity or 'reciprocal altruism'. ${ }^{84}$ This incentive expresses the reciprocal and solidary concept of giving and receiving inherent in the act of donation. ${ }^{85}$ In doing so, it addresses the unfairness of having a significant part of the population unwilling to donate organs, but ready to receive them in case of need. ${ }^{86}$ Allocation priority also offers the advantage of retaining a link with health care. ${ }^{87}$

The incentive of allocation priority necessitates the creation of an official organ donor register. ${ }^{8}$ Such a register operates as a computerized electronic database that records and centralizes consent expressed by willing potential organ donors. The register is accessible electronically for authorized individuals, such as transplant coordinators of organ procurement organizations and personnel from hospital intensive care units. To avoid abuse, a waiting period is necessary between registration and the moment when priority can be granted. ${ }^{89}$ This safeguard addresses the risk of strategic behavior, ie individuals registering only once they are sick and in need of an organ. Registered donors can revoke their consent at any given moment.

Israel offers the incentive of allocation priority for registered donors as part of its public policy to promote organ donation. As the Israeli system is one of the few

82 British Medical Association, supra note 46, at 52; Ben Saunders, supra note 2, at 379; Mark S. Nadel \& Carolina A. Nadel, supra note 1, at 312ff; Jennifer A. Chandler, supra note 50, at $109 \mathrm{ff}$.

83 Nurit Guttman et al., supra note 54, at 694; Gil Siegal \& Richard J. Bonnie, supra note 52, at 417; Jennifer A. Chandler, supra note 50, at 101.

84 Jacob Lavee \& Avraham Stoler, Reciprocal Altruism-The Impact of Resurrecting an Old Moral Imperative on the National Organ Donation Rate in Israel, 77 L. \& ConTEMP. Probs. 323 (2014); Jonathan G. August, supra note 31, at 411; Jacob Lavee et al., supra note 25, at 784; Alexandra K. Glazier, The Principles of Gift Law and the Regulation of Organ Donation, 24 TransPL. INT. 368, 371 (2011); Benjamin F. Gruenbaum \& Alan Jotkowitz, The Practical, Moral, and Ethical Considerations of the New Israeli Law for the Allocation of Donor Organs, 42 Transpl. Proc. 4475, 4476 (2010); Gil Siegal \& Richard J. Bonnie, supra note 52, at 416; Mark S. Nadel \& Carolina A. Nadel, supra note 1 , at 320.

85 Ben Saunders, supra note 2, at 379. Siegal et al. suggest a shift from personal altruism to collective and reciprocal obligations. They present a 'reciprocity-based social contract approach'. However, they do not consider an allocation priority incentive, but a system of presumed consent. See Gil Siegal \& Richard J. Bonnie, supra note 52 , at $416 \mathrm{ff}$.

86 Jacob Lavee \& Dan W. Brock, Prioritizing Registered Donors in Organ Allocation: An Ethical Appraisal of the Israeli Organ Transplant Law, 18 CURR. OPIN. CRIT. CARE 707 (2012); Muireann Quigley et al., Organ Donation and Priority Points in Israel: An Ethical Analysis, 93 Transplantation 970, 971 (2012); Govert Den Hartogh, Priority to Registered Donors on the Waiting List for Postmortal Organs? A Critical Look at the Objections, $37 \mathrm{~J}$. Med. Ethics 149, 149 (2011); Nurit Guttman et al., supra note 54, at 695.

87 Gert VAn DijK \& Medard T. Hilhorst, supra note 4, at 9.

88 Mark S. Nadel \& Carolina A. Nadel, supra note 1, at 315. On the characteristics of various organ donor registers worldwide, see Amanda M. Rosenblum et al., Worldwide Variability in Deceased Organ Donation Registries, 25 TRANSPL. INT. 801, 801ff (2012).

89 Mark S. Nadel \& Carolina A. Nadel, supra note 1, at 314; Jennifer A. Chandler, supra note 50, at 110. 
currently operating incentives in the world, we will present this example in greater detail below. ${ }^{90}$

'Allocation priority', based on reciprocity, is also conceivable for 'living donation'. Such an incentive grants priority for organs from deceased donors to living donors should the need occur in the future. ${ }^{91}$ Living donors receive waiting list priority since they not only express willingness to donate but actually give up an organ. Such an incentive reassures living donors that in the event their remaining kidney fails, it is likely that they receive another one promptly. Some states currently grant allocation priority to living donors. The United Network for Organ Sharing in the USA, for example, operates an allocation priority system for living donors. ${ }^{92}$

\section{IV.C. Financial incentives}

Tax credits, discounts on health insurance premiums, and contributions to funeral costs are 'indirect financial incentives'. They offer a symbolic reward for the gesture of donation. ${ }^{93}$

A 'tax credit' is an indirect financial incentive for dead and living donation. ${ }^{94}$ As an instrument of social policy, tax benefits are by no means exceptional. Donations to charities, for example, can be listed on one's tax declaration to claim a credit. ${ }^{95}$ For dead donation, this incentive offers an annual fixed tax credit (for example, \$500) to individuals who manifest their consent and register as potential organ donors after death. ${ }^{96}$ Registered donors can retract their consent at any time. They keep the tax benefits for the time they were registered and hence potential organ donors. Granting an annual symbolic tax credit bears fewer risks of abuse than offering a much larger single tax credit the year an individual expresses his consent to donation. It also avoids the tricky question of what happens when an individual withdraws his consent. The introduction of a tax incentive for dead donation necessitates the creation of an official organ donor

90 See section IV.D.

91 British Medical Association, supra note 46, at 53; Gilbert T. Thiel, A Bonus-System for Previous or Declared Organ Donors, in Case they Need an Organ themselves, in ETHICAL, LEGAL, AND Social Issues IN OrgantransPLANTATION 68 (Thomas Gutmann et al. ed., 2004).

92 Michele Goodwin, supra note 2, at 98; Jennifer A. Chandler, supra note 50, at 117; Francis L. Delmonico et al., supra note 81 , at $1628 \mathrm{ff}$.

93 The literature also discusses monetary contributions to charities in the donor's or his relatives' name. See Faisal Omar et al., supra note 4, at 158; John B. Dossetor, supra note 4, at 318ff; Dilip S. Kittur et al., supra note 4, at 1442. To incentivize post mortem organ donation, China has launched two financial compensation policies. The 'thank you' form is an expression of gratitude on behalf of the Red Cross Society of China for consenting to donation. The 'help' form is social welfare support for needy families: Xiaoliang Wu \& Qiang Fang, Financial Compensation for Deceased Organ Donation in China, 39 J. MED. ETHICs 378, 378 (2013).

94 Satel et al. distinguish between a more generous tax credit and a deduction: Sally L. Satel \& David C. Cronin, supra note 4, at 1329.

95 John B. Dossetor, supra note 4, at 318ff; Frederick R. Parker et al., Organ Procurement and Tax Policy, 2 Hous. J. Health L. \& POL'y 173, 179 (2002); Jonathan Herring, Giving, Selling and Sharing Bodies, in Body LORE AND Laws 55 (Andrew Bainham et al. ed., 2002).

96 Thomas S. Petersen \& Kasper Lippert-Rasmussen, supra note 4, at 452; Jurgen De Wispelaere \& Lindsay Stirton, Advance Commitment: An Alternative Approach to the Family Veto Problem in Organ Procurement, $36 \mathrm{~J}$. Med. Eтhics 180 (2010); Joseph B. Clamon, Tax Policy as a Lifeline: Encouraging Blood and Organ Donation Through Tax Credits, 17 Ann. Health L. 67 (2008); Frederick R. Parker et al., supra note 95, at 175ff; Andrew J. Oswald, Economics that Matters: Using the Tax System to Solve the Shortage of Human Organs, 54 KYKLOS 379, 380 (2001). 
register. ${ }^{97}$ As an incentive for living donation, an organ donor receives a one-time tax credit in the year of the donation. ${ }^{98}$ Tax incentives for living donors are implemented, for example, in some states of the USA..$^{99}$

A discount on 'health insurance premiums' is another indirect financial incentive for dead and living donation. It offers the advantage of retaining a link with health care. ${ }^{100}$ For dead donation, the reward is granted to individuals who manifest their consent to organ donation after death. ${ }^{101}$ Registered donors benefit from an annually fixed discount on their health insurance premiums for every year of registration. The registration can be revoked at any time. This incentive necessitates the creation of an official organ donor register. The Netherlands introduced such an incentive in 2008, offering a discount of 10 percent on annual health insurance premiums, which amounts to a reward of about $€ 120 .{ }^{102}$ Unfortunately little to nothing is known about whether this system is still operating, and if so, under which circumstances. A discount on health insurance premiums can also be offered as an incentive for living donation. In this case, the discount is granted either only once the year the donation takes place, or as a lifelong exemption from health insurance premiums. ${ }^{103}$

A 'funeral benefit' is also an indirect financial incentive. Here the state participates in covering funeral expenses of deceased donors. A fixed contribution toward funeral costs is offered to the deceased's relatives and paid directly to the funeral home. ${ }^{104}$ In many countries, a similar system of covering funeral expenses is in place for individuals who donate their bodies to research and medical schools for educational purposes. In the context of medical research and education, this long existing incentive is uncontroversial in today's society. According to the Nuffield Council, it 'appears to be regarded by both professionals and families as an appropriate acknowledgement of the person's gift'. ${ }^{105}$ An analogous incentive is conceivable to promote organ donation, as the same logic applies for a contribution toward funeral costs of organ donors. In the UK, the Nuffield Council favors such a contribution granted by the National Health Service. ${ }^{106}$ The US state of Pennsylvania has discussed a regulatory framework for such an incentive. It has not introduced it, however, due to doubts as to its compatibility with the US

97 Frederick R. Parker et al., supra note 95, at 177.

98 Thomas S. Petersen \& Kasper Lippert-Rasmussen, supra note 4, at 452; Sean Arthurs, supra note 10, at 1102; Frederick R. Parker et al., supra note 95, at 179.

99 For an overview of relevant legislation in all the states of the USA, see https://transplantliving.org/ financing-a-transplant/living-donation-costs/ (accessed Mar. 14, 2018).

100 Gert VAn DijK \& Medard T. Hilhorst, supra note 4, at 9.

$101 \mathrm{Id}$. at 18.

102 Sally L. Satel, Conclusion, in When Altruism Isn't Enough: The CASE For Compensating Kidney Donors 122 (Sally L. Satel ed., 2008).

103 GeRT VAN Dijk \& MEDARD T. Hilhorst, supra note 4, at 42.

104 Sally L. Satel \& David C. Cronin, supra note 4, at 1329; Nuffield CounCIL ON BioethiCs, supra note 3, at 175; Gert VAn Dijk \& Medard T. Hilhorst, supra note 4, at 21; Steve P. Calandrillo, supra note 4, at 115; Shelby E. Robinson, supra note 2, at 1038; Dilip S. Kittur et al., supra note 4, at 1442; Thomas G. Peters, Life or Death: The Issue of Payment in Cadaveric Organ Donation, 265 JAMA 1302, 1302ff (1991).

105 NufField COUNCIL ON BIOETHiCs, supra note 3, at 175.

106 Beyond this specific recommendation, the report asserts that state incentives for organ donation pass the ethics test, under certain conditions. The British Medical Association also 'does not have major ethical concerns about offering funeral expenses to those on the Organ Donor Register who go on to donate organs'. See British Medical Association, supra note 46, at 65. 
National Organ Transplant Act. ${ }^{107}$ Spain operates a publicly funded program offering assistance with funeral expenses to relatives of post mortem donors. ${ }^{108}$

A futures market and a regulated organ market are two 'direct financial incentives', as they offer a purchase price for an organ.

A 'futures market' is a direct financial incentive for dead donation. According to Hansmann, it can be defined as 'the right to harvest a person's organs upon death (...) purchased from him while he is alive and well'. ${ }^{109}$ The potential seller signs a legally binding sales contract with the state as the only admissible buyer. ${ }^{110}$ This contract authorizes the state to retrieve the organs upon the seller's death in exchange for the payment of a standard price fixed by the regulatory framework. ${ }^{111}$ The contract is executed once the seller's death is confirmed and only in case the organs are suitable for transplantation. ${ }^{112}$ The purchase price is then transferred to the seller's estate or a designated beneficiary.

Finally, a 'regulated organ market' is a direct financial incentive for dead and living donation. ${ }^{113}$ In a regulated organ market, the state is the sole authorized purchaser ('single buyer concept'). The state buys organs for a fixed price from willing sellers. ${ }^{114}$ The sellers are either close relatives in the case of post mortem donation or the living donor (or seller) in the case of living donation. This incentive involves a 'spot market', in contrast to the above-mentioned 'futures market'. ${ }^{115}$ Iran is the only state in

107 Michele Goodwin, supra note 2, at 149ff; Peter A. Ubel et al., Pennsylvania's Voluntary Benefits Program: Evaluating an Innovative Proposal for Increasing Organ Donation, 19 HeALth AFF. 206 (2000). For the proposal discussed in the state of Pennsylvania, see Sally L. Satel et al., supra note 4, at $240 \mathrm{ff}$.

108 David Rodríguez-Arias et al., supra note 43, at 1110.

109 Henry Hansmann, supra note 2, at 62.

110 Philippe Steiner, supra note 60, at 497; Gloria J. Banks, Legal \& Ethical Safeguards: Protection of Society's Most Vulnerable Participants in a Commercialized Organ Transplantation System, 21 AM. J. L. MED. 45, 97 (1995); Lloyd R. Cohen, supra note 2, at 30; Richard Schwindt \& Aidan R. Vining, supra note 2, at 489. The futures market can be operated directly by the state, a governmental entity, or through a publicly mandated organization such as an existing organ procurement organization.

111 Gregory S. Crespi, supra note 2, at 1ff; Lloyd R. Cohen, supra note 2, at 1ff; Henry Hansmann, supra note 2, at 57ff; Richard Schwindt \& Aidan R. Vining, supra note 2, at 483ff; Marvin Brams, supra note 2, at 187. On the fixed price, in particular, see Gregory S. Crespi, supra note 2, at 43; Lloyd R. Cohen, supra note 2, at 35.

112 The futures market raises the legally challenging question of whether the potential seller should abide by a healthy lifestyle (nutrition, alcohol consumption, and physical activity) to preserve his organs in a condition that makes them suitable for transplantation (!). See Melanie Mader, supra note 4, at 494; Gloria J. Banks, supra note 110 , at 97.

113 See note 2.

114 British Medical Association, supra note 46, at 56; Charles A. Erin \& John Harris, supra note 2, at 137; Charles A. Erin \& John Harris, supra note 2, at 134ff. The regulated market can be operated directly by the state or through a publicly mandated organization such as an existing organ procurement organization. In the literature, the appropriate sales prices vary according to specific criteria. Organs from living donors (or sellers) are more valuable than organs from dead donors (or sellers) for quality reasons. See T. Randolph Beard \& Jim Leitzel, supra note 2, at 283; Sally L. Satel, supra note 102, at 126; David C. Cronin \& Julio J. Elias, Operational Organization of a System for Compensated Living Organ Providers, in WHEN ALtruism IsN'T Enough: The Case for Compensating Kidney Donors 38 (Sally L. Satel ed., 2008); Gert Van Dijk \& Medard T. Hilhorst, supra note 4, at 41; Michele Goodwin, supra note 2, at 159; Arthur J. Matas \& Mark A. Schnitzler, Payment for Living Donor (Vendor) Kidneys: A Cost-Effectiveness Analysis, 4 Am. J. TransPlanT 216 (2004).

115 Gloria J. Banks, supra note 110, at 76. 
the world that legally permits a market in kidneys from living donors since $1997 .{ }^{116}$ The Iranian government provides a fixed compensation of approximately $\$ 1200$ plus health insurance coverage for one year. The donor also receives remuneration from the recipient or from charitable organizations. The kidney waiting list in Iran seems to have disappeared within a short period. ${ }^{117}$ Black market activities have also been eradicated, as the regulated kidney market is accessible only to Iranian donors and recipients. ${ }^{118}$ One of the negative aspects of the Iranian system is the insufficient medical follow-up care that is provided to donors. ${ }^{119}$ Also, as several scholars show, the majority of compensated kidney donors in Iran are exposed to financial pressures motivating donation, express dissatisfaction about how the regulated system is administered, and fear social stigma. $^{120}$

\section{IV.D. Concrete example: allocation priority in Israel}

To date, only a few states have considered incentives as a regulatory tool to promote organ donation in the context of a public policy. One of the exceptions is Israel. In 2008, Israel became the first country in the world to enact legislation incorporating the incentive of allocation priority based on individuals' willingness to donate into its organ procurement system. ${ }^{121}$

In March 2008, the Israeli Parliament adopted a new Organ Transplantation Law. ${ }^{122}$ This law was enacted as a response to particularly low organ donation rates. Its primary purpose is to increase the number of organs donated in Israel and curb

116 Benjamin E. Hippen, Organ Sales and Moral Travails - Lessons from the Living Kidney Vendor Program in Iran, POLICy ANALYSIS 1, 4 (2008); Thomas Eich, Organtransplantation und Organhandel im Iran, in KommerZIAL-

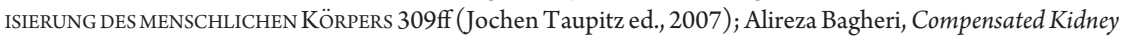
Donation: An Ethical Review of the Iranian Model, 16 KenNEDy Inst. ETHICS J. 269, 271 (2006); Iraj Fazel, Renal Transplantation in Iran: The Iranian Model, in ETHICAL, LEGAL, AND SOCIAL IsSUES IN ORGANTRANSPLANTATION 282 (Thomas Gutmann et al. ed., 2004).

117 Benjamin E. Hippen, supra note 116, at 2; Alireza Bagheri, supra note 116, at 271.

118 Benjamin E. Hippen, supra note 116, at 4; Alireza Bagheri, supra note 116, at 275.

119 Benjamin E. Hippen, supra note 116, at 5.

120 Sigrid Fry-Revere et al., Coercion, Dissatisfaction, and Social Stigma: An Ethnographic Study of Compensated Living Kidney Donation in Iran, Int. Urol. Nephrol. (2018) (Epub ahead of print); Allison Tong et al., The Experiences of Commercial Kidney Donors: Thematic Synthesis of Qualitative Research, 25 TRANSPL. INT. 1138 (2012).

121 Muireann Quigley et al., supra note 86, at 970; Muireann Quigley, supra note 4, at 89ff; Nurit Guttman et al., supra note 54, at 692. In its system of presumed consent, Singapore offers priority to individuals who do not opt out. See Human Organ Transplant Act 1987, section 12(1). See also Jacob Lavee et al., supra note 25, at 784; Govert Den Hartogh, supra note 86, at 149; Mark S. Nadel \& Carolina A. Nadel, supra note 1, at 313; Jennifer A. Chandler, supra note 50, at 117. Chile also implemented a priority allocation system. Like Singapore, Chile has an opt-out rule and grants priority to individuals who have not opted out. See Alejandra Zúñiga-Fajuri, Increasing Organ Donation by Presumed Consent and Allocation Priority: Chile, 93 WHO BuLL. 199 (2015).

122 The Organ Transplantation Law 5768-2008. Israeli Book of Laws. An English translation is available at http://www.declarationofistanbul.org/resources/legislation (accessed Mar. 14, 2018). For a historical overview of organ transplantation in Israel, see Jacob Lavee \& Avraham Stoler, supra note 84, at 323ff. See also Jacob Lavee et al., supra note 25, at 781; Jacob Lavee et al., A New Law for Allocation of Donor Organs in Israel, 375 The LANCET 1131 (2010); Linda Wright \& Diego S. Silva, supra note 4, at 1233. 
transplant tourism to developing countries. ${ }^{123}$ The allocation priority incentive is operational since 1 April 2012. ${ }^{124}$

The Israeli incentive of allocation priority offers a relative priority on the waiting list, in the form of additional points. The system is based on relative priority: the attitude of a patient toward organ donation is not the only allocation criteria, but one among several. Medical necessity is still the highest priority. However, if two patients on the transplant waiting list have equal medical need for an organ, priority will be given to (a) individuals whose first-degree relative has donated organs after death; (b) non-directed and directed living donors; (c) individuals who expressed their consent to donate organs after death by signing a donor card; (d) individuals whose first-degree relative has signed a donor card. ${ }^{125}$ These four categories are weighed differently. Categories (a) and (b) are granted top priority, as they involve an actual organ donation that occurred in the past. Category (c) receives second priority, and category (d) third priority. ${ }^{126}$ Should an individual fall into more than one category, only the highest priority is relevant, as priorities cannot be cumulated. Individuals under the age of 18 and those incapable of giving consent receive relative priority status. ${ }^{127}$

The Israeli incentive is original because it grants allocation priority to different categories of individuals. It offers reassurance to living donors should they need an organ at some point in their lives (category b). The incentive also intends to motivate individuals to register as potential donors during their lifetime (category c), and to encourage individuals to donate deceased first-degree relatives' organs (category a). Although individuals can register as organ donors, the decision whether to donate organs or not remains with the potential donor's first-degree relatives. ${ }^{128}$ Category a of the priority system thus provides an incentive for the very people expressing consent to organ donation. Furthermore, as an unusual feature, the Israeli system grants priority not only to registered donors, but also to their first-degree relatives who have not signed a donor card

123 Jacob Lavee \& Avraham Stoler, supra note 84, at 327ff; Gil Siegal, Making the Case for Directed Organ Donation to Registered Donors in Israel, 3 ISR. J. HeALTH POL'y RES. (2014); Vardit Ravitsky, supra note 4, at 381; Jacob Lavee et al., supra note 25, at 780; Benita Padilla et al., supra note 22, at 916; Asif Efrat, supra note 25, at 1650; Asif Efrat, supra note 22, at 83; Muireann Quigley et al., supra note 86, at 970; Benjamin F. Gruenbaum \& Alan Jotkowitz, supra note 84 , at 4475 . For a fascinating study of sociocultural factors shaping the moral perceptions, discourses, practices, and public policies regarding organ trafficking in Israel, see Zvika Orr, International Norms, Local Worlds: An Ethnographic Perspective on Organ Trafficking in the Israeli Context, in ORGAN Transplantation: Ethical, Legal and Psychosocial Aspects. Global Issues, Local Solutions 39ff(W. Weimar et al. ed., 2014).

124 Jacob Lavee \& Avraham Stoler, supra note 84, at 327; Jacob Lavee et al., supra note 25, at 781; Benita Padilla et al., supra note 22, at 916. The Israeli Organ Transplantation Law also includes a set of measures to remove disincentives for living donation. See Jacob Lavee \& Avraham Stoler, supra note 84, at 326; Jacob Lavee et al., supra note 25, at 781; Benita Padilla et al., supra note 22, at 916; Tamar Ashkenazi et al., supra note 23, at 1301 .

125 Jacob Lavee \& Avraham Stoler, supra note 84, at 326; Jacob Lavee et al., supra note 25, at 781; Benita Padilla et al., supra note 22, at 916; Muireann Quigley et al., supra note 86, at 971; Jacob Lavee et al., supra note 122, at 1131 .

126 Jonathan G. August, supra note 31, at 412; Jacob Lavee, Ethical Amendments to the Israeli Organ Transplant Law, 13 Am. J. Transplant 1614, 1614 (2013); British Medical Association, supra note 46, at 53; Muireann Quigley et al., supra note 86, at 971; Jacob Lavee et al., supra note 122, at 1131.

127 Nurit Guttman et al., supra note 54, at 698; Jacob Lavee et al., supra note 122, at 1132; Benjamin F. Gruenbaum \& Alan Jotkowitz, supra note 84, at 4476.

128 Avraham Stoler et al., Incentivizing Authorization for Deceased Organ Donation With Organ Allocation Priority: The First 5 Years, 16 Am. J. Transplant 2639, 2640 (2016). 
(category d). According to Brazier \& Harris, this may be explained by the fact that donation 'is perceived as a family enterprise and the "reward" is shared by the family. ${ }^{129}$ This prioritization category is problematic though. It allows individuals unwilling to consent to donation themselves to benefit from the good actions of others, ie first-degree relatives. ${ }^{130}$ Awarding priority to individuals because a first-degree relative has signed an organ donor card is unfair, as it is unrelated to an individual's behavior and intent, and does not adhere to the concept of reciprocity. It also advantages individuals with an extended family.

The Israeli Organ Transplantation Law imposes a three-year waiting period, ie individuals have to be registered as a potential organ donor for three years before they can potentially claim to benefit from the allocation priority. ${ }^{131}$

Public awareness campaigns explaining the allocation priority system at all levels of education within the population are essential to guarantee equality among potential patients. The introduction of the incentive in Israel was thus accompanied by a large multilingual campaign about organ donation through various media channels such as radio, TV, billboards, and newspaper ads. ${ }^{132}$

The response of the population was significant. Numerous individuals registered as potential organ donors. During the 10 weeks of the public awareness campaign preceding the new law's implementation, 70,000 Israelis signed up for organ donor cards. In addition to the substantial rise in newly registered potential donors, consent rates for deceased organ donation increased, and the number of organs available for transplantation rose in parallel. ${ }^{133}$ The preliminary and short-term data on the effectiveness of the new Israeli allocation priority system as a regulatory tool for improving donation rates thus seemed positive. ${ }^{134}$

A recent study evaluating in more detail the first five years after the adoption of the new incentive comes to the same conclusion. ${ }^{135}$ The study shows that Israel's allocation priority incentive has so far had a substantial effect on organ donor registrations and authorization rates for organ donation. Most importantly, it highlights that this effect goes significantly beyond the increased awareness created through the large information campaigns, which took place before the incentive was implemented in 2012. According to the study, the authorization rate for organ donation reached an all-time high rate of 60 percent in 2015 . $^{136}$ Interestingly, this increase was mainly due to an increase

129 Margaret Brazier \& John Harris, supra note 50, at 24.

130 Jonathan G. August, supra note 31, at 416; Jacob Lavee, supra note 126, at 1614; Jacob Lavee \& Dan W. Brock, supra note 86, at 707ff; Muireann Quigley et al., supra note 86, at 971; Benjamin F. Gruenbaum \& Alan Jotkowitz, supra note 84 , at 4477.

131 Jacob Lavee, supra note 126, at 1614; Jacob Lavee et al., supra note 25, at 781; Muireann Quigley et al., supra note 86, at 971; Margaret Brazier \& John Harris, supra note 50, at 27; Nurit Guttman et al., supra note 54, at 698.

132 Jacob Lavee et al., supra note 122, at 1132; Benjamin F. Gruenbaum \& Alan Jotkowitz, supra note 84, at 4476.

133 Jacob Lavee et al., supra note 25, at 781; Benita Padilla et al., supra note 22, at 915ff; Muireann Quigley et al., supra note 86 , at 972 .

134 Jacob Lavee et al., supra note 25, at 780ff. The Organ Transplantation Law introduced not only an allocation priority incentive but also other changes, eg regarding living donor compensation and prohibition of transplant tourism. The increase in transplantation activities is thus not solely attributable to the described incentive.

135 Avraham Stoler et al., supra note 128, at 2639ff.

136 Id. at 2641. 
in the authorization rate of next of kin of unregistered donors ( $51.1 \%$ vs $42.2 \%)$, an increase which is probably linked to the incentive's priority category a. ${ }^{137}$ The study also found that the likelihood of next-of-kin authorization for donation was approximately twice as high when the deceased relative was a registered donor rather than unregistered ( $89.4 \%$ vs $44.6 \%){ }^{138}$ This result reveals the importance of increasing organ donor registrations through the allocation priority incentive, as 'more registrations translate into a higher likelihood that authorization for donation will be granted'. ${ }^{139}$ Considering the overall positive results, it appears that Israel's nuanced regulatory design of its incentive, offering allocation priority not only to registered potential organ donors but also to next of kin that authorize organ retrieval on deceased donors, is key to its success. These nuances speak to the various motives that can underlie the decision to donate and take into account that in reality organ donation is not only an individual decision but also a family matter. Finally, one may note that the priority incentive has a real practical impact on organ allocation in Israel. In 2014, 30 percent of transplanted patients were advanced in line based on their priority status; in 2015, this percentage increased to 32 percent. ${ }^{140}$

The incentive introduced in Israel thus serves as a promising regulatory example for other states, as it is likely to make more organs available for transplantation. It will be interesting to monitor if the positive effect on the number of individuals registered as organ donors and organs donated persists over time.

\section{LEGAL CONSTRAINTS}

\section{V.A. Prohibition of organ sales}

From a legal perspective, state incentives for organ donation raise a crucial question: Are they compatible with the prohibition of organ sales and, more generally, the prohibition of deriving benefit from the human body and its parts?

The prohibition of organ sales is enacted first of all in international law. The Council of Europe's Convention on Human Rights and Biomedicine is the most important reference here. ${ }^{141}$ This convention imposes legally binding obligations on the 29 member states having ratified its text. According to article 21 ('Prohibition of financial gain'), ' $(t)$ he human body and its parts shall not, as such, give rise to financial gain'. Article 21 of the Council of Europe's Additional Protocol on Transplantation ${ }^{142}$ refines the prohibition established by the convention by excluding not only financial gain but also any other comparable advantage in exchange for an organ. The same article allows for exceptions to this rule, such as compensation of living donors for loss of earnings and other justifiable expenses. Article 22 of the Additional Protocol on Transplantation prohibits organ trafficking. ${ }^{143}$

\footnotetext{
Id. at 2641.

138 Id. at 2641.

139 Id. at 2643.

140 Id. at 2642.

141 Council of Europe, Convention for the Protection of Human Rights and Dignity of the Human Being with regard to the Application of Biology and Medicine (Convention on Human Rights and Biomedicine), Apr. 4, 1997, ETS $\mathrm{n}^{\circ} 164$.

142 See note 40.

143 On July 9, 2014, the Committee of Ministers of the Council of Europe adopted the Convention against Trafficking in Human Organs (ETS n ${ }^{\circ} 216$ ).
} 
Other international norms also refer to the prohibition of organ sales. A prominent legally non-binding text is the Resolution on the Guiding Principles on Human Cell, Tissue and Organ Transplantation adopted by the World Health Organization (WHO). ${ }^{144}$ Principle 5 states that organs 'should only be donated freely, without any monetary payment or other reward of monetary value. Purchasing, or offering to purchase (...) organs for transplantation, or their sale by living persons or by the next of kin for deceased persons, should be banned'. The WHO Guiding Principles allow for compensation of expenses for living donation.

The European Union legal framework is also relevant, as it imposes legally binding obligations on the 26 member states. Article 3 ('Right to the integrity of the person') of the Charter of Fundamental Rights imposes a 'prohibition on making the human body and its parts as such a source of financial gain'. ${ }^{145}$ According to Article 13 of Directive 2010/45/EU, 'donations of organs from deceased and living donors are voluntary and unpaid'. ${ }^{146}$ This 'principle of non-payment' does not exclude compensation of expenses for living donors.

The prohibition of organ sales is a broadly recognized legal principle, not only in international, but also in domestic law. ${ }^{147}$ It is enacted on a national level by most legal systems in the developed world. ${ }^{148}$ The literature occasionally describes the prohibition of organ sales as a global legal principle, as the ban is, de jure at least, nearly global. ${ }^{149}$ The prohibition of organ sales is not an absolute legal principle tough, as it is subject to exceptions. In many states, regulation of living donation allows for financial compensation (eg reimbursement of lost income, time off work, travel and medical expenses, life and disability insurance). ${ }^{150}$

144 World Health Organization (WHO), Guiding Principles on Human Cell, Tissue and Organ Transplantation, as endorsed by the sixty-third World Health Assembly in May 2010 (Resolution WHA 63.22).

145 European Union, Charter of Fundamental Rights of the European Union, Official Journal of the European Union, Mar. 30, 2010 (2010/C 83/02).

146 Directive 2010/45/EU of the European Parliament and of the Council of 7 July 2010 on Standards of Quality and Safety of Human Organs Intended for Transplantation.

147 Ingrid Schneider, supra note 4, at 198; Jean V. Mchale, Organ Transplantation, the Criminal Law, and the Health Tourist A Case for Extraterritorial Jurisdiction?, 22 Cамв. Q. Healthс. Ethics 64, 67ff(2013); Melanie Mader, supra note 4, at 83ff; Elyse Skura, supra note 56, at 461; CounCIL OF EUROPE \& UNITED NATIONS, supra note 22, at 47; Mark S. Nadel \& Carolina A. Nadel, supra note 1, at 310.

148 The GLObal ObSERVATORY On DONATION AND Transplantation provides a database on existing legal frameworks: http://www.transplant-observatory.org (accessed Mar. 14, 2018). For a concrete example, see the Swiss legal framework: the Swiss Constitution ('Any donation of human organs (...) must be free of charge. The trade in human organs is prohibited', article 119a) and the Swiss Transplantation Act of 2007 ('It is prohibited to grant or derive financial gain or any other advantage from a donation of human organs', article 6; also article 7).

149 Ingrid Schneider, supra note 4, at 198; Ingrid Schneider, Die Nicht-Kommerzialisierung des Organtransfers als Gebot einer Global Public Policy: Normative Prinzipien und gesellschaftspolitische Begründungen, in KoMMERZIALISIERUNG DES MENSCHLICHEN KÖRPERS 109ff (Jochen Taupitz ed., 2007). De facto the situation looks different, as transplantation medicine hardly operates in a money-free environment. Organ trafficking, transplant tourism, and black market activities are flourishing in certain parts of the developing world.

150 Alberto Giubilini, Why and How to Compensate Living Organ Donors: Ethical Implications of the New Australian Scheme, 29 Bioethics 283 (2015); Atheendar Venkataramani et al., The Impact of Tax Policies on Living Organ Donations in the United States, 12 Am. J. TRansplant 2133 (2012). The Research Service of the US Congress published a report on this issue: Congressional Research Service, Report for Congress - Living Organ Donation and Valuable Consideration (2007). 
To evaluate the compatibility of state incentives with the prohibition of organ sales, the underlying normative rationale becomes relevant. An analysis of its normative history and intent shows that this legal principle prohibits private commercial transactions involving money between the donor, the recipient, and third parties (eg organ brokers, intermediaries). ${ }^{151}$ The prohibition of organ sales intends to prevent abuse in transplantation medicine. Its purpose is to (a) protect donors and recipients, who are in a vulnerable position, by preserving their dignity and avoiding undue inducement and exploitation; (b) guarantee equal access to organs, unrelated to a patient's capacity and willingness to pay; (c) maintain safety in transplantation medicine; and (d) combat transplant tourism and organ trafficking.

Within a legal framework honoring the prohibition to derive benefit from the human body and its parts, there is a strong normative position against attributing a monetary value to organs and making them part of private commercial dealings between individuals. ${ }^{152}$ However, state incentives promoting consent to organ donation are not equivalent to a purchase price for an organ. ${ }^{153}$ They neither assign a monetary value to organs nor involve them in commercial transactions. ${ }^{154}$ An incentive is a public policy instrument, ${ }^{155}$ a reward for the gesture of donation, which is a generous act of solidarity with patients in need and society. ${ }^{156}$ It is understood, by all parties, in terms of reward to the person for their act of providing bodily material, rather than a purchase of material itself. 157

State incentives do hence not violate the prohibition of organ sales and are in line with its underlying normative rationale, under certain conditions. Adequate and proportionate expressions of appreciation and gratitude by the state in the context of a public policy are compatible with existing legal frameworks prohibiting organ sales. Satel et al. suggest a 'reasonableness standard' for evaluating state incentives designed to encourage organ donation. ${ }^{158} \mathrm{We}$ argue here that as public policy instruments, nonfinancial and indirect financial incentives pass the reasonableness test. Direct financial

151 Scholars analysing the prohibition of organ sales in various jurisdictions come to the same conclusion. For the Council of Europe's Convention on Human Rights and Biomedicine, its Additional Protocol on Transplantation, and Swiss Law, see the detailed analysis in Melanie Mader, supra note 4, at 255ff. For German Law: CARSTEN ROTH, EIGENTUM AN KÖRPERTEILEN: RECHTSFRAGEN DER KOMMERZIALISIERUNG DES MENSCHLICHEN KÖRPERS 86ff (2009). For the US National Organ Transplant Act (NOTA): Sally L. Satel et al., supra note 4, at $217 \mathrm{ff}$.

152 Alena M. Buyx, supra note 4, at 16; Margaret J. Radin, supra note 2, at 1849ff. Satel et al. present an interesting analysis of the legislative history and intent of the prohibition of organ sales in the USA. They show that references to business and contract law dominate the language used in congressional debates preceding the adoption of the prohibition: Sally L. Satel et al., supra note 4, at $222 \mathrm{ff}$.

153 Nuffield Council on Bioethics, supra note 3, at 170. Satel et al. note that the 'state is not buying organs. Rather, "as sovereign" and through "an act of government," the state is bestowing its bounty on citizens who have engaged in behavior of which the state approves'. Sally L. Satel et al., supra note 4, at 233. Contra: Alexandra K. Glazier \& Francis L. Delmonico, The Declaration of Istanbul Is Moving Forward by Combating Transplant Commercialism and Trafficking and by Promoting Organ Donation, 12 AM. J. Transplant 515, 515 (2012): 'Public policy that promotes such incentives becomes veiled programs of organ sales'.

154 Thomas S. Petersen \& Kasper Lippert-Rasmussen, supra note 4, at 455; Muireann Quigley, supra note 4, at $89 \mathrm{ff}$.

155 For the USA, Satel et al. note that '( $\mathrm{g}$ )overnment disbursements that are intended as gratuities or incentives advancing a public-policy purpose fall outside the language and intent of NOTA section 301(a)', the legal provision prohibiting organ sales in the USA. See Sally L. Satel et al., supra note 4, at 221.

156 On the concept of solidarity as an inherent attribute of the act of donation, see section III.C.

157 NufField COUNCIL ON BiOETHICS, supra note 3, at 170.

158 Sally L. Satel et al., supra note 4, at $220 \mathrm{ff}$. 
incentives (ie regulated organ market; futures market) have to be ruled out though. As they offer a purchase price and implicate legally binding sales contracts, they violate the prohibition of organ sales. ${ }^{159}$

For future law reform introducing state incentives, it is advisable to amend present legal frameworks on organ procurement and clarify that such incentives do not violate the prohibition of organ sales. ${ }^{160}$ The regulatory technique of creating an exception for state incentives can be applied in an analogous way to how current regulations circumscribe compensation for living donors. ${ }^{161}$ Another example is how regulations of scientific research allow for coverage of funeral expenses for individuals who donate their bodies to research or medical education after death.

\section{V.B. Just allocation of organs}

Beyond the prohibition of organ sales, state incentives raise other legal issues. For nonfinancial incentives, the central question refers to the just allocation of organs, as medical resources are to be distributed based on medical need and not merit. ${ }^{162}$ The just allocation of organs is an expression of the legal principles of equal treatment and nondiscrimination.

Both international and domestic laws explicitly and implicitly adhere to the just allocation of organs. Article 3 of the Council of Europe's Additional Protocol on Transplantation, for example, states that organs shall be allocated in conformity with transparent, objective, and duly justified rules according to medical criteria. Within national legal frameworks, organs are generally allocated based on the following criteria: medical urgency, medical efficiency (ie compatibility between donor and recipient), and waiting time. $^{163}$

Granting allocation priority to registered donors adds a criterion. It takes into account a patient's previously expressed willingness to donate and attributes a certain priority on the waiting list to patients who are registered organ donors. An individual's registration to donate organs after death is not a medical criterion though. Does offering allocation priority for registered donors thus violate the principle of just allocation of organs and equal treatment and non-discrimination more generally? ${ }^{164}$

First of all, today's organ allocation system does not adhere to medical criteria only. The time spent on the waiting list is not strictly speaking a medical criterion. Also,

159 Nikola Biller-Andorno \& Alexander M. Capron, supra note 2, at 1390; Annette Rid et al., Would You Sell a Kidney in a Regulated Kidney Market? Results of an Exploratory Study, 35 J. MED. ETHICs 558, 558 (2009); Francis L. Delmonico, supra note 2, at 29ff. According to the Nuffield Council, body parts are not to be purchased directly, ie 'where money exchanges hands in direct return for body parts (rather than to reward or recompense donors for their act of donation)': NUfFIELD COUNCIL ON BIOETHICS, supra note 3, at 9.

160 For a proposal of such an amendment in Swiss law, see Melanie Mader, supra note 4, at 441ff.

161 See for example article 21 of the Council of Europe's Additional Protocol on Transplantation; article 6 of the Swiss Transplantation Act of 2007.

162 Govert Den Hartogh, supra note 86, at 150; Nurit Guttman et al., supra note 54, at 695; Benjamin F. Gruenbaum \& Alan Jotkowitz, supra note 84 , at 4476.

163 For an overview of existing legal frameworks, see The GLOBAL ObSERVATORY ON DONATION AND TRANSPLANTATION, supra note 148). For Swiss Law, see article 18 of the Swiss Transplantation Act of 2007. Article 119a of the Swiss Constitution imposes in general terms 'the fair allocation of organs'. For the USA and Canada: Jennifer A. Chandler, supra note 50, at 103.

164 We have analysed the legal principles of equal treatment and non-discrimination in detail elsewhere, see Melanie Mader, supra note 4, at 539ff. For a US constitutional law analysis, see Jonathan G. August, supra note 31 , at $413 \mathrm{ff}$. 
organs obtained through directed living donation between family members are not allocated according to medical criteria. Organ allocation in living donation depends on a patient's 'moral luck' in having an extended family or other social network willing to go through donor screening and eventually consent to be a living donor. ${ }^{165}$

Second, a patient's status as a registered organ donor is an objective and transparent criterion. ${ }^{166}$ It is distinct from social worth criteria such as one's political function, eg a head of state, one's profession, such as a doctor, or one's family status, eg a mother of four young children. ${ }^{167}$ Social worth criteria are inherently subjective and thus incompatible with the principle of just allocation of organs. Furthermore, it is critical to acknowledge that transplantation medicine cannot exist without organ donors. There is a close conceptual and causal link between individuals' willingness to donate and the number of organs available. ${ }^{168}$ As such, allocation priority is not a morally arbitrary factor for the distribution of the scarce good of human organs. ${ }^{169}$

Third, potential donors having manifested their willingness to donate are in a different position than individuals opposing organ donation after death. The previously expressed donative intent of some patients on the waiting list is sufficient to categorize them as dissimilar and hence allows for treating them differently. Although social values and context may influence an individual's stance on organ donation, it cannot be considered as an inherent or deeply rooted part of his personality that is not susceptible to change. In addition, treating individuals differently according to their manifested willingness to donate organs does not entail a negative value judgement of non-donors. The decision of individuals who due to religious or cultural beliefs refuse to donate their organs after death has to be respected in all circumstances. It is morally doubtful though that an individual refusing donation due to such beliefs demands to benefit from the very same generosity or 'sacrifice' that he is not willing to make himself. ${ }^{170}$ The allocation priority incentive does not exclude such 'free riders' from receiving an organ, but allocates a preference for registered donors in case of equal medical need. ${ }^{171}$

Finally, allocation priority for registered donors is a criterion that promotes important social values, as it relates to solidarity among the members of a society. ${ }^{172}$ It also concretizes the principle of justice and realizes the concept of reciprocity, which as discussed above is an inherent and essential attribute of the act of donation. ${ }^{173}$

165 I. Glenn Cohen, supra note 2, at $96 \mathrm{ff}$.

166 Adnan Sharif, supra note 67, at 1611; Mark S. Nadel \& Carolina A. Nadel, supra note 1, at 321.

167 Melanie Mader, supra note 4, at 542.

168 Govert Den Hartogh, supra note 86, at 150; Jennifer A. Chandler, supra note 50, at 123.

169 '(W)illingness to donate one's organs - in contrast to other personal characteristics, such as race or "social worth" - is a morally relevant difference and justifies preferential access to donated organs': COMMITTEE ON INCREASING RATES OF ORGAN DONATION, supra note 49, at 255. On the notion of arbitrariness in the context of organ allocation, see I. Glenn Cohen, supra note 2, at 97f; Govind Persad et al., Principles for Allocation of Scarce Medical Interventions, 373 THE LANCET 423, 425 (2009).

170 Jacob Lavee \& Dan W. Brock, supra note 86, at 707ff; Govert Den Hartogh, supra note 86, at 150; Margaret Brazier \& John Harris, supra note 50, at 28; Mark S. Nadel \& Carolina A. Nadel, supra note 1, at 324.

171 Jacob Lavee \& Avraham Stoler, supra note 84, at 329. On the notion of 'free-riders', see Jacob Lavee et al., supra note 25, at 780; Muireann Quigley et al., supra note 86, at 971; Jennifer A. Chandler, supra note 50, at $122 \mathrm{ff}$.

172 Govind Persad et al., supra note 169 , at 426.

173 Muireann Quigley et al., supra note 86, at 971; Govert Den Hartogh, supra note 86, at 149; Nurit Guttman et al., supra note 54, at 695 . On the principle of justice in medical ethics, see TOM L. BEAUCHAMP \& JAMES F. Childress, Principles of Biomedical Ethics 249ff (2013). 
Granting allocation priority does hence not a priori violate the principles of just allocation of organs, equal treatment, and non-discrimination. However, as all regulatory tools, such a state incentive has to comply with the principle of proportionality. Only an incentive that offers relative priority, and not an absolute one, is proportionate. Designed in this manner, the registration as an organ donor is one among several allocation criteria. Moreover, a system granting allocation priority to registered donors has to take into account special circumstances, such as 'super urgent' patients, children, and adults incapable of giving valid consent, and allow for exceptions in these cases. ${ }^{174}$

\section{V.C. Voluntary consent}

Financial incentives raise the question of voluntary consent. Consent is the legal and ethical cornerstone of all medical interventions, its purpose being to protect an individual's autonomy and physical integrity. Article 5 of the Council of Europe's Convention on Human Rights and Biomedicine and articles 13 and 17 of its Additional Protocol on Transplantation require freedom of consent for organ donation. The same is true for domestic legal frameworks. ${ }^{175}$

Offering a significant sum of money to an individual struggling with financial difficulties may affect his capacity to consent to organ donation freely. Many scholars express concern for the risk of undue inducement or coercion of destitute individuals when considering exchanges of money and organs. ${ }^{176}$ However, state incentives first and foremost value the donor's or his relatives' consent. They are not necessarily incompatible with the requirement of voluntary consent, depending on the incentives' modalities and the safeguards enacted. Most importantly, financial incentives must adhere to the principle of proportionality.

For post mortem donation, the issue of undue inducement is less relevant, since there is no harm to the donor or his relatives, and one does not need one's organs after death. Living donation is more challenging because the donor agrees to assume health risks. As such, the safeguards to be implemented relate to the following aspects. ${ }^{177}$ First, a meticulous screening process of potential donors is necessary, including medical and psychological evaluation. Second, a waiting period between the decision to donate and the actual donation gives the donor the opportunity to reflect and reconsider. Third, a non-cash (ie indirect financial) reward, possibly granted in installments spread over

174 British Medical Association, supra note 46, at 54; Melanie Mader, supra note 4, at 544ff; Govert Den Hartogh, supra note 86, at 149; Jennifer A. Chandler, supra note 50, at 110; Paul T. Schotsmans, The Principle of Reciprocity in Organ Allocation, in ETHICAL, LEgal, AND Social Issues In Organtransplantation 342 (Thomas Gutmann et al. ed., 2004); Gilbert T. Thiel, supra note 91, at 68ff. For the case of individuals with specific diseases that need an organ, but are unable to donate (eg patients with HIV), see Muireann Quigley et al., supra note 86, at 972; Muireann Quigley, supra note 4, at 89ff; Govert Den Hartogh, supra note 86, at 149; Mark S. Nadel \& Carolina A. Nadel, supra note 1, at 315; Jennifer A. Chandler, supra note 50, at 111.

175 For an overview of domestic laws, see The Global ObSERVATORY ON DONATiON AND TransPlantation, supra note 148). For Swiss Law, see articles 8 and 12 of the Swiss Transplantation Act of 2007.

176 Kate Greasley, A Legal Market in Organs: the Problem of Exploitation, 40 J. MED. ETHICs 51, 51ff (2014); Rob Lawlor, Organ Sales: Exploitative at any Price?, 28 BIOETHICS 194 (2014); Vardit Ravitsky, supra note 4, at 380; Alexandra K. Glazier \& Francis L. Delmonico, supra note 153, at 515; Rob Lawlor, Organ Sales Needn'T Be Exploitative (But it Matters If They are), 25 Bіоетнісs 250 (2011). On the terminological differences between coercion, exploitation, and undue inducement, see I. Glenn Cohen, supra note 2, at 75ff; I. Glenn Cohen, supra note 22 , at $273 \mathrm{ff}$.

177 T. Randolph Beard \& Jim Leitzel, supra note 2, at 273 and 283; I. Glenn Cohen, supra note 2, at 90; Sally L. Satel et al., supra note 4, at 228; GERT VAN DijK \& MEDARD T. Hilhorst, supra note 4, at 9. 
time, allows excluding individuals desperate for money. The installments can also be linked to the donor's adherence to medical follow-up.

Indirect financial incentives granting a symbolic reward, if possible spread over time, do not exercise undue inducement on the potential donor or his close relatives. ${ }^{178} \mathrm{Such}$ incentives fulfill the requirement of voluntary consent. A regulated market or a futures market are problematic, however, as they offer a considerable amount of money and thus raise concerns about the quality of consent. ${ }^{179}$

\section{V.D. Recognition of property rights in organs}

Finally, financial incentives raise the question of property rights in organs. A regulated organ market and a futures market imply signing a legally binding sales contract involving organs between the potential seller or his relatives and the state. Recognition of property rights in organs is, therefore, necessary to realize these two direct financial incentives. ${ }^{180}$ Is the seller himself holder of such rights, or are his relatives?

From a theoretical point of view, the concept of property rights in organs is not $a$ priori impossible to conceive of. ${ }^{181}$ The recognition of such rights remains controversial though, both among scholars and in cases adjudicated by courts in various jurisdictions. ${ }^{182}$ This controversy constitutes another valid reason, although more pragmatic than normative, to rule out the direct financial incentives of a regulated organ market and a futures market.

\section{ETHICAL CONSIDERATIONS}

The positive consequences of an increased number of available organs are manifest. Promoting organ donation is hence not only ethically justifiable but also necessary. ${ }^{183}$

178 T. Randolph Beard \& Jim Leitzel, supra note 2, at 255ff; Faisal Omar et al., supra note 4, at 160ff.

179 Kate Greasley, supra note 176, at 51ff; Simon Rippon, Imposing Options on People in Poverty: The Harm of a Live Donor Organ Market, 40 J. Med. ETHICs 145 (2014); Rob Lawlor, supra note 176, at 194ff; Vardit Ravitsky, supra note 4, at 380; Alexandra K. Glazier \& Francis L. Delmonico, supra note 153, at 515; Rob Lawlor, supra note 176, at 250ff; Annette Rid et al., supra note 159, at 558.

180 Barbro Björkman \& Sven Ove Hansson, Bodily Rights and Property Rights, 32 J. MED. ETHICs 209 (2006).

181 We have discussed this issue in detail elsewhere: Melanie Mader, supra note 4, at $358 \mathrm{ff}$.

182 Kristin Zeiler, supra note 60, at 171ff; Ingrid Schneider, supra note 4, at 201; Remigius N. Nwabueze, Body Parts in Property Theory: An Integrated Framework, 40 J. MED. ETHICS 33 (2014); Teck Chuan Voo \& Soren Holm, Organs As Inheritable Property?, 40 J. Med. EтHICs 57 (2014); Christian Lenk \& Katharina Beier, Is the Commercialisation of Human Tissue and Body Material forbidden in the Countries of the European Union?, 38 J. Med. Ethics 342 (2012); Remigius N. Nwabueze, Donated Organs, Property Rights and the Remedial Quagmire, 16 Med. L. Rev. 201 (2008); Remigius N. NWABUEZe, BioteChNOlOgy AND the CHALlenge of PROPERTY: PROPERTY RIGHTS IN DEAD BODIES, BODY PARTS, AND GENETIC INFORMATION 35ff (2007); ROHAN J. Hardcastle, Law And the Human Body: Property Rights, Ownership And Control 25ff (2007); Radhika Rao, Genes and Spleens: Property, Contract, or Privacy Rights in the Human Body?, 35 J. L. Med. ETHICS 371 (2007); Barbro Björkman \& Sven Ove Hansson, supra note 180, at 209ff; Melissa A.W. Stickney, Property Interests in Cadaverous Organs: Changes to Ohio Anatomical Gift Law and the Erosion of Family Rights, 17 J. L. \& Health 37 (2002); David Price, supra note 67, at 386; Margaret J. Radin, Contested Commodities: The Trouble with Trade in Sex, Children, Body Parts, and Other Things 21 (1996); Lloyd R. Cohen, supra note 2, at 18; Margaret J. Radin, supra note 2, at 1849ff. See also J. MED. ETHICS, Jan. 2014, Vol. 1. For relevant judicial decisions in the USA, see Colavito v. New York Donor Network, No. 4, 486 F.3d 78 (2d Cir. 2007); Washington University v. Catalona, 437 F. Supp. 2 d 985 (Dist. Ct. Missouri 2006); Greenberg v. Miami Children's Hospital, 264 F. Supp. 2d 1064 (S.D. Fla. 2003); Moore v. Regents of the University of California, 793 P.2d 479 (Cal. 1990).

183 An ethical analysis of incentives is of course not limited to a consequentialist or utilitarian perspective. The four principles of biomedical ethics developed by Beauchamp \& Childress are far more useful in this context. 
The question is not whether the state should encourage individuals' willingness to donate, but how. State incentives raise ethical issues though. We will address some of the most relevant ones, without claiming to depict an exhaustive picture of the ethical discussion here.

\section{VI.A. Origin of organs and exploitation}

Unlike a system of presumed consent, incentives for organ donation value the donor's autonomy and demand explicit consent. ${ }^{184}$ However, based on consequentialist reasoning and the liberal concept of individual autonomy, incentives raise the question of the organs' origin.

Donors may disproportionately come from lower socioeconomic parts of society. Schneider notes the risk of 'socio-economic selectivity in donor recruitment'. ${ }^{185}$ Destitute individuals are more likely to accept financial incentives than those who are welloff. A certain asymmetry in organ procurement in a state incentivized system is probably unavoidable. This concern of equity and distributive justice as to the burden of providing organs for transplantation is in our opinion the most problematic point of encouraged donation.

However, is this asymmetry in organ procurement equivalent to state-sponsored exploitation of the poor? Unfortunately, societal asymmetry is not a phenomenon unique to encouraged organ donation. In many areas of life, individuals from a lower socioeconomic background more often perform tasks implicating a particular risk or burden. ${ }^{186}$ Incentivized organ donation at least benefits the entire population, irrespective of one's financial situation, through a larger pool of available organs. ${ }^{187}$

The welfare of the donor and the potential for harm and exploitation are key considerations when designing a system of state incentives. ${ }^{188}$ To alleviate the potential asymmetry and avoid exploitation of donors, safeguards have to be implemented. ${ }^{189}$ These safeguards pertain to assuring that consent to donate one's organs is voluntary and informed. We have discussed above safeguards such as screening

We have discussed the work of Beauchamp \& Childress in detail elsewhere: Melanie Mader, supra note 4, at $317 \mathrm{ff}$.

184 T. Randolph Beard \& Jim Leitzel, supra note 2, at 255ff; Working Group on Incentives for Living Donation, supra note 4, at 308; Thomas S. Petersen \& Kasper Lippert-Rasmussen, supra note 4, at 452f. On the principle of autonomy in medical ethics, see Tom L. BEAUCHAMP \& JAMES F. ChILDRESS, supra note 173, at 101ff.

185 Ingrid Schneider, supra note 4, at 208. See also Mark Schweda \& Silke Schicktanz, supra note 36, at 260; Thomas S. Petersen \& Kasper Lippert-Rasmussen, supra note 4, at 454; Faisal Omar et al., supra note 4, at 160; Margaret Brazier \& John Harris, supra note 50, at 25.

186 For example, the participation in remunerated clinical trials. See Christine Grady, Vulnerability in Research: Individuals with Limited Financial and/or Social Resources, 37 J. L. MED. ETHICS 19, $23 \mathrm{ff}(2009)$; GERT VAN DiJK \& MEDARD T. HilHorsT, supra note 4, at 37.

187 Some scholars note that individuals with a lower socioeconomic status are disproportionately represented among patients suffering from end-stage renal disease and waiting for a kidney. As such, there is a certain balance between burdens and benefits. See eg Henry Hansmann, supra note 2, at 74 .

188 NufFIELD COUNCIL ON BioETHiCs, supra note 3, at 156. On the principles of beneficence and non-maleficence in medical ethics, see TOM L. BEAUCHAMP \& JAMES F. CHILDRESS, supra note 173, at 202ff. On the principle of beneficence in the context of organ donation, see Jennifer A. Chandler, supra note 50, at 119; Robert Arnold et al., supra note 4, at 1367. Beyond exploitation and coercion, the ethical literature also deals with harm, in particular to the potential kidney vendor in a regulated organ market. See the AM. J. BIOETHICS, Oct. 2014, Vol. 14.

189 Kate Greasley, supra note 176, at 51ff; Simon Rippon, supra note 179, at 145ff; Faisal Omar et al., Compensated Living Kidney Donation: A Plea for Pragmatism, 18 Health Care ANAL. 85, 95 (2010). On the terminological 
potential living donors, imposing a waiting period, and granting incentives in installments over time. ${ }^{190}$ Also, the issue of exploitation renders non-financial incentives such as allocation priority particularly attractive, as the reward they provide is appealing to everyone, independently of an individual's wealth. ${ }^{191}$

\section{VI.B. Commodification of the human body}

Incentives also raise the issue of the human body as a potential source of commercial activity and financial gain. The Declaration of Istanbul, adopted in 2008 at an international conference organized by the Transplantation Society and the International Society of Nephrology, defines transplant commercialism as a 'policy or practice in which an organ is treated as a commodity, including by being bought or sold or used for material gain'. 192

Relying on deontological reasoning, numerous scholars criticize transplant commercialism and commodification of the human body more generally, based on the view that the human body is exceptional. ${ }^{193}$ However, this principled critic is usually directed toward private commercial transactions and markets involving human body parts.

Can state incentives impair individuals' and society's respect for the integrity of the human body? Do such incentives lead to transplant commercialism and commodification? Current legal frameworks do not allow for organs to be tradable objects with monetary value. Offering state incentives reflects a conceptually different approach though. These public policy tools value the act of donation and express society's gratitude and appreciation for the donor. ${ }^{194}$ Incentives take into account the concept of reciprocity that is inherent in the act of donation. According to Schweda \& Schicktanz, incentives 'correspond to the reciprocal spirit of gift exchange and do not adhere to a profit-oriented logic of the marketplace'. ${ }^{195}$ They hence contribute to a more accurate expression of the gift relationship in transplantation medicine.

differences between coercion, exploitation, and undue inducement, see I. Glenn Cohen, supra note 2, at 75ff; I. Glenn Cohen, supra note 22, at $273 \mathrm{ff}$.

190 See section V.C.

191 Nurit Guttman et al., supra note 54, at 695; Jennifer A. Chandler, supra note 50, at 128. It is true, however, that non-financial incentives, such as pool-cross-over transplantation, which usually involve close family members, might involve other risks of exploitation or coercion, such as family pressure. This is not the case with the nonfinancial incentive of allocation priority.

192 The Declaration of Istanbul was first published on July 5, 2008 in 372 The LANCET 5 (2008). See http://www.declarationofistanbul.org/index.php (accessed Mar. 14, 2018).

193 The deontological reasoning primarily relies on Immanuel Kant's doctrine of virtues and duties: IMMANUEL Kant, GrundLEGUNG ZUR Metaphysik der Sitten (1965). See for example British Medical Association, supra note 46, at 59; Alexandra K. Glazier \& Francis L. Delmonico, supra note 153, at 515; Margaret Brazier \& John Harris, supra note 50, at 25; Faisal Omar et al., supra note 189, at 96; Stephen Wilkinson, Commodification Arguments for the Legal Prohibition of Organ Sale, 8 HeAlth CARE ANAL. 189 (2000); Lesley A. Sharp, The Commodification of the Body and Its Parts, 29 AnNu. Rev. ANTHRopol. 287 (2000); MARGARET J. RADIN, supra note 182, at 21 and 97 . Schneider refers to the 'exceptional position held by the human body': Ingrid Schneider, supra note 4, at 200. Malmqvist presents a principled approach to body or body part exceptionalism: Erik Malmqvist, Does the Ethical Appropriateness of Paying Donors Depend on What Body Parts They Donate?, 19 Med. Health Care Phil. 463, 465ff (2016). The commodification argument is also raised in pragmatic objections based on 'slippery slope' arguments. See Tom L. BEAUChamp \& JAMES F. ChILdREss, supra note 173, at 146; Alena M. Buyx, supra note 4, at 15.

194 Muireann Quigley, supra note 4, at 89ff; GERT VAN DijK \& MEDARD T. HilHorst, supra note 4, at 17.

195 Mark Schweda \& Silke Schicktanz, supra note 62, at 1134. 


\section{VI.C. Threat to altruism}

A communitarian ethical argument relates to the threat to altruism that incentives might pose. Considering the organ shortage, altruism alone is an unsuccessful doctrine in transplantation medicine. ${ }^{196}$ However, it should continue to play a central role in ethical thinking about organ donation. As the Nuffield Council states, the idea of altruistic donation - giving bodily material because another person needs it — underpins a communal and collective approach where generosity and compassion are valued'. ${ }^{197}$ We argue here that altruism should remain at the heart of donation, as it reflects important community values. However, this does not exclude the possibility of introducing a reward. ${ }^{198}$

State incentives for organ donation are conceived as a facilitator for altruism. ${ }^{199}$ They are neither threat nor replacement. Incentivized donation retains an altruistic component and preserves the solidary character of the act of donation, although other motives may play a role as well. As Barnieh et al. note, 'assuming that incentives obliterate all altruistic motives is undoubtedly too simple a picture for human behavior' ${ }^{200}$ Promoting desirable prosocial behavior through incentives is a standard tool in the arsenal of state regulation. Offering tax incentives to encourage monetary donations to charitable organizations for example, and thus rewarding generous individuals who do something good, is a common and well-accepted public policy instrument. Such a tax credit does not undermine the altruistic intent of the donor. As Petersen \& LippertRasmussen state, 'tax breaks for ordinary donations to charity have not changed their meaning such that they are no longer thought of as gifts' ${ }^{201}$

Altruism and state incentives to encourage individuals' willingness to donate are hence not mutually exclusive. ${ }^{202}$ Donation of certain body parts, which allows for compensation, such as sperm and egg donation, is still considered a donation, and not an act adhering to market principles only. By communicating a message of gratitude and appreciation, state incentives do not bring about a systemic change in today's conception of organ donation. ${ }^{203}$ Incentives have 'the potential to achieve significantly increased donation rates within the existing gift law paradigm', as they honor the gift relationship. ${ }^{204}$ Implemented in the context of a public policy, they preserve the paradigm of donation as a generous and solidary act, not only with recipients but also with society.

196 Sally L. Satel \& David C. Cronin, supra note 4, at 1329; Faisal Omar et al., supra note 189, at 99; Mark S. Nadel \& Carolina A. Nadel, supra note 1, at 295; Jennifer A. Chandler, supra note 50, at 130. On the notion of altruism in the context of organ donation, see Chloe Sharp \& Gurch Randhawa, supra note 2, at 163ff; Greg Moorlock et al., Altruism in Organ Donation: An Unnecessary Requirement?, 40 J. Med. ETHICs 134 (2014); Ben Saunders, supra note 2, at 377; Robert Arnold et al., supra note 4, at 1365.

197 Nuffield COUNCIL ON Bioethics, supra note 3, at 8.

198 For an opinion to the contrary, see for example Teck Chuan Voo, Altruism and Reward: Motivational Compatibility in Deceased Organ Donation, 29 BIOETHICs 190, 190ff (2015).

199

Faisal Omar et al., supra note 189, at 97.

200 Lianne Barnieh et al., supra note 54, at 1961.

201 Thomas S. Petersen \& Kasper Lippert-Rasmussen, supra note 4, at 454.

202 T. Randolph Beard \& Jim Leitzel, supra note 2, at 286; BRITISH MEDICAL Association, supra note 46, at 62; Nuffield Council on Bioethics, supra note 3, at 132ff; GerT VAn DijK \& Medard T. Hilhorst, supra note 4, at 10. For an opinion to the contrary, see Teck Chuan Voo, supra note 198, at 190ff.

203 See also sections III.C and V.A.

204 Alexandra K. Glazier, supra note 84, at 371. 


\section{VI.D. National self-sufficiency and global social justice}

An ethical analysis of state incentives for organ donation has to reflect on transnational or global issues. The occurrence of transplant tourism and organ trafficking is evident. ${ }^{205}$ In most cases, it involves patients unable or unwilling to wait for an organ in their developed country of origin. They thus travel to a developing country, in which the prohibition of organ sales is not (sufficiently) enforced, and buy an organ from a destitute and vulnerable local 'donor'.

This exploitative situation is problematic. It is inherently unfair to export the 'developed world' problem of organ shortage to developing countries. Based on a framework of global social justice, states have a moral responsibility to aim for and achieve national self-sufficiency of organs within their borders. ${ }^{206}$ In the literature, calls are made for government accountability to achieve national self-sufficiency in organ donation and transplantation. Delmonico et al. note that 'a new paradigm of national self-sufficiency is urgently needed', and '( $\mathrm{g}$ )overnments can no longer abdicate responsibility for the organ donation and transplantation needs of their people'. ${ }^{207}$ The Declaration of Istanbul of 2008 contains similar claims. ${ }^{208}$

The extent and practical details of this accountability, and possible means to achieve national self-sufficiency, vary in the literature. One aspect, however, is certain. By striving to establish national self-sufficiency in kidneys and reducing waiting lists, the developed world can diminish its contribution to the demand driving today's black market activities. $^{209}$

\section{PUBLIC PERCEPTION AND ACCEPTANCE OF INCENTIVES}

\section{VII.A. Design of information campaigns}

Reinforcing the population's trust in the transplantation system and building a positive societal climate for organ donation are important objectives. Appropriate public health communication has to accompany the introduction of incentives, as a necessary pillar of effective public policy. The purpose of information campaigns is to raise the public's awareness of the organ shortage, change social attitudes toward donation, and bring about social change.

We argue here that the contributory causes of the organ shortage are to be highlighted in these campaigns. Through public health communication, the state informs

205 I. Glenn Cohen, supra note 22, at 263ff; I. Glenn Cohen, supra note 22, at 269ff; Alireza Bagheri \& Francis L. Delmonico, supra note 22, at 887ff; Benita Padilla et al., supra note 22, at 915ff; Asif Efrat, supra note 25, at 1650ff; Asif Efrat, supra note 22, at 764ff; Asif Efrat, supra note 22, at 81; Nancy Scheper-Hughes, supra note 22, at 26; Nancy Scheper-Hughes, supra note 22, at 1645ff; Nancy Scheper-Hughes, supra note 22, at 191ff.

206 Schneider refers to 'international social injustice' in this context: Ingrid Schneider, supra note 4, at 209. For a general development of the concept of national responsibility and global justice, see DAVID MILLER, NATIONAL ReSPONSIBILITY AND GLOBAL JUSTICE $111 \mathrm{ff}$ (2007).

207 Francis L. Delmonico et al., A Call for Government Accountability to Achieve National Self-sufficiency in Organ Donation and Transplantation, 378 THE LANCET 1414, 1414 (2011). See also Mark Schweda \& Silke Schicktanz, supra note 36, at 256; NUFFIELD COUNCIL ON BIOETHICS, supra note 3, at 195. For a critical analysis of the related issue of national self-sufficiency in the context of the system of national balance points, which is applied in transnational cooperation on organ transplantation in Europe, see Konstantin Tretyakov, A Critique of National Solidarity in Transnational Organ Sharing in Europe, 5 J. L. \& BIOSCI. 1 (2018).

208 See note 192.

209 I. Glenn Cohen, supra note 22, at 282; Thomas S. Petersen \& Kasper Lippert-Rasmussen, supra note 4, at 455; Faisal Omar et al., supra note 189, at 92. 
the population about the impact of civilization diseases on the growing need for organs. ${ }^{210}$ This is a novel and crucial point. Today it is not part of public knowledge that the rising prevalence of obesity, hypertension, and type 2 diabetes steadily increases the need for kidney transplantation.

The organ shortage remains an abstract and unspecific concern for a majority of the population. Linking civilization diseases, which are omnipresent in public discourse, to the need for organs confronts individuals with an obvious and concrete need. It is an issue everyone can relate to personally, which might address the attitude/action gap and thus facilitate the decision to consent to organ donation. Within the same framework, public health communication can also expose the fact that one is much more likely to be in need of an organ transplant one day than to become an actual organ donor, ie to die in circumstances that allow for organ retrieval. ${ }^{211}$

Furthermore, it is crucial to communicate that 75 percent of patients on the waiting list need a kidney. ${ }^{212}$ Svenaeus has recently provided detailed phenomenological analyses of the connection between transplantable body parts and the personal identity of those who provide or receive them. ${ }^{213}$ According to another study by Sperling \& Gurman, kidneys do not have a very symbolic meaning. ${ }^{214}$ They do not play an essential role in one's perception of self or one's 'sense of self. Kidneys are thus less connected to personal identity, in contrast to other organs, such as the eyes or the heart. Sperling \& Gurman show that there is a significant link between the closeness of an organ to a donor's sense of self and his willingness to donate. Public health communication should, therefore, emphasize the need for kidneys to display a concrete need individuals can relate to. Campaigns refocused in this manner can lower internal barriers that individuals encounter when contemplating organ donation as an abstract concept, and facilitate expression of consent to kidney donation.

\section{VII.B. Public opinion, effectiveness, and legitimacy}

Transplantation medicine thrives on trust in its abilities and integrity. Beard \& Leitzel describe this trust as an 'independent public good'. ${ }^{215}$ Trust is an issue because of the particular circumstances surrounding post mortem organ donation. If this trust is damaged by the introduction of state incentives, current rates of organs donated might fall even further. It is well documented in the literature that in the aftermath of scandals related to listing and allocation decisions donation rates tend to drop. ${ }^{216}$ State incentives thus have to be regulated and implemented so as not to interfere with the public's trust.

210 The 'role of preventable diseases in the increasing demand for organs should be publicised in order to add weight to public health campaigns': NufFIELD COUNCIL ON BioETHICS, supra note 3, at 12.

211 Sam D. Shemie et al., Lifetime Probabilities of Needing an Organ Transplant Versus Donating an Organ After Death, 11 Am. J. Transplant 2085 (2011).

212 On the specific issue of the kidney shortage, see Philip J. Cook \& Kimberly D. Krawiec, supra note 15, at $1 \mathrm{ff}$.

213 Fredrik Svenaeus, The Lived Body and Personal Identity: The Ontology of Exiled Body Parts, in BoDILY EXCHANGes, BIOethics ANd border Crossing: Perspectives ON GIVING, SElling ANd SHARING bodies $19 \mathrm{ff}$ (Erik Malmqvist \& Kristin Zeiler ed., 2016).

214 Daniel Sperling \& Gabriel M. Gurman, Factors Encouraging and Inhibiting Organ Donation in Israel, 9 J. BIOETH. INQ. 479, 485ff (2012). On body phenomenology and embodiment in the context of organ donation, see Kristin Zeiler, supra note 60, at $171 \mathrm{ff}$.

215 T. Randolph Beard \& Jim Leitzel, supra note 2, at 280.

216 Annette Dufner \& John Harris, Trust and Altruism-Organ Distribution Scandals: Do They Provide Good Reasons to Refuse Posthumous Donation?, 40 J. Med. PHILOs. 328 (2015). 
Transparency regarding the incentives offered and criteria used for donor qualification and organ allocation is of utmost importance to maintain and reinforce this trust.

Public perception and acceptance of state incentives are empirical questions. The same is true for the effectiveness of such incentives in increasing donation rates. Opinion polls have tested the public's attitude toward incentives throughout the developed world. These polls show a nuanced picture of the public's support for or opposition against incentives. Appropriate and proportionate incentives are received in a rather positive manner, whereas market approaches including a cash payment are generally opposed. ${ }^{217}$ Schweda \& Schicktanz describe that “

the relevant and precarious demarcation line between what is viewed as acceptable or not does not seem to set monetary against non-monetary forms of incentives, but rather the reciprocal spirit of gift exchange against the profit-oriented logic of the marketplace. $(\ldots \mathrm{T})$ his perspective implies that models involving money are not perceived as objectionable per se, as long as they are compatible with the principle of reciprocity, which holds true e.g. for forms of compensation and 'rewarded giftin'. ${ }^{218}$

These results call for careful consideration, as reported patterns of potential behavior may not translate entirely into actual behavior of expressing consent to organ donation. However, they support our conceptual development of state incentives as an alternative to the altruism versus market dichotomy.

The legitimacy of state incentives eventually depends on their ability to boost the number of organs: '(m)oving away from a system based solely on altruism would only be worthwhile if there is good reason to believe that it will achieve this aim'. ${ }^{219}$ Introducing state incentives through pilot projects is hence an appropriate regulatory approach. Such projects will help understanding how financial or non-financial incentives influence individuals' willingness to donate. ${ }^{220}$ The empirical question of whether incentives are an effective tool to improve donation rates can only be tested in real life.

Since non-financial and financial incentives are well-established public policy tools, in particular in public health, we can expect that the same approach fits organ

217 For Europe, see M. C. Van Buren et al., For Love or Money? Attitudes Toward Financial Incentives Among Actual Living Kidney Donors, 10 Am. J. TransPlant 2488 (2010); Mark Schweda \& Silke Schicktanz, supra note 62, at 1130; Leonieke Kranenburg et al., Public Survey of Financial Incentives for Kidney Donation, 23 NePHROL. Dial. Transplant 1039 (2008); Friedrich Breyer eT AL., supra note 16, at 171. UK and US studies present the same results: Firat Bilgel \& Brian Galle, Financial Incentives for Kidney Donation: A Comparative Case Study using Synthetic Controls, 43 J. Health ECON. 103 (2015); Christopher T. Robertson et al., Perceptions of Efficacy, Morality, and Politics of Potential Cadaveric Organ Transplantation Reforms, 77 L. \& CONTEMP. PROBS. 101, $110 \mathrm{ff}$ (2014); Gill Haddow, 'Because You're Worth It?' The Taking and Selling of Transplantable Organs, 32 J. MED. EтHICs 324, 327 (2006); Cindy L. Bryce et al., supra note 4, at 2999ff. For studies from Canada, see Jacquelyn A. Burkell et al., Attitudes Toward Reciprocity Systems for Organ Donation and Allocation for Transplantation, 38 J. Health Pol. Pol’y L. 957 (2013); Jennifer A. Chandler et al., Priority in Organ Allocation to Previously Registered Donors: Public Perceptions of the Fairness and Effectiveness of Priority Systems, 22 ProG. Transplant 413 (2012); Lianne Barnieh et al., supra note 54, at $1956 \mathrm{ff}$.

218 Mark Schweda \& Silke Schicktanz, supra note 62, at 1134. For similar findings, see Klaus Hoeyer et al., Public Attitudes to Financial Incentive Models for Organs: A Literature Review Suggests That It Is Time to Shift the Focus From 'Financial Incentives' to 'Reciprocity', 26 Transpl. InT. 350 (2013).

219 British Medical Association, supra note 46, at 65.

220 Sally L. Satel \& David C. Cronin, supra note 4, at 1329; Arthur J. Matas et al., supra note 4, at 1957; Faisal Omar et al., supra note 189, at 98; Michele Goodwin, supra note 2, at $111 \mathrm{ff}$. 
donation too. ${ }^{221}$ Introducing incentives thus has a promising potential for expanding organ availability. Finally, the results of the allocation priority incentive introduced in Israel in 2012 are encouraging, as the number of organs donated has increased significantly so far.

\section{CONCLUSIONS}

Promotion of organ donation has become an important public health issue, as the situation of transplantation medicine in the developed world is critical. We have described here the empirical data of the organ shortage and its medical, social, and economic consequences. The current situation will deteriorate if today's legal frameworks for organ procurement remain the same, considering the challenges of an aging population, a serious growth in civilization diseases, no alternative treatments in the foreseeable future and considerable health care costs. At this point, the organ shortage cannot be addressed by scientific or medical advances, but rather requires political action and regulatory solutions.

Reducing the organ shortage has many desirable consequences. First of all, fewer patients succumb to organ failure and die. Second, the quality of life of individuals waiting for an organ improves, notably for the many patients undergoing dialysis. Third, the cost burden for health care systems is alleviated, since kidney transplantation presents a favorable cost-effectiveness ratio as a treatment for end-stage renal disease. Fourth, wider availability of organs is medically advantageous, as it allows for improved quality of donor-recipient matches and reduction of second transplants. Finally, transplant tourism and organ trafficking in developing countries decrease.

Based on the critical public interests at stake, we argue that it is the state's responsibility to further the availability of organs for transplantation purposes. The distinctive role of the state in transplantation medicine is one of stewardship, for patients waiting for an organ and organ donation more generally.

In analogy to other public health problems, the state can implement various regulatory tools to fight the organ shortage. From a public health perspective, the state has not only an obligation to promote organ donation (supply side) but also to

221 Richard Titmuss, in his groundbreaking work The Gift Relationship published in 1971, argued that introducing a market in blood had the paradoxical effect of reducing overall supply by crowding out intrinsic altruistic motivation for donating. See Richard M. Titmuss, The Gift Relationship: From Human Blood to SOCIAL POLICY 198 and 245 (1971; re-edition in 1997). This claim has also been dealt with in more recent work on behavioral economics and motivational crowding out, in particular by Frey: BRUNO S. FREY, NOT JUST FOR THE MONEY: AN ECONOMIC THEORY OF PERSONAL MOTIVATION 35ff (1997); Bruno S. Frey \& Felix Oberholzer-Gee, The Cost of Price Incentives: An Empirical Analysis of Motivation Crowding-Out, 87 AM. ECON. REv. 746 (1997). However, other scholars have criticized this approach: Benjamin E. Hippen \& Sally L. Satel, supra note 4, at 96ff; Robert M. Solow, Blood and Thunder, 80 YALE L. J. 170, 173ff (1971); Kenneth J. Arrow, Gifts and Exchanges, 1 PHIL. PUB. AfF. 343, 350 (1972). There is in fact a lack of empirical evidence as to the existence of a crowding out effect, as noted by Sally L. Satel et al., supra note 4, at 229; I. Glenn Cohen, supra note 2, at 74; Julia D. Mahoney, supra note 2, at 24ff. The crowding out of altruistic organ donations by state incentives has not been analysed so far, but seems unlikely. As Petersen et al. state: 'In general, tax incentives strengthen the pattern of behaviour they render more financially attractive': Thomas S. Petersen \& Kasper Lippert-Rasmussen, supra note 4, at 453. Titmuss also argued that a compensated system would procure organs of inferior quality, as potential donors would be tempted to lie about their diseases and general health condition. Scholars have demonstrated that this argument based on public health and safety concerns is not relevant in today's context for organ procurement and transplantation, which allows for appropriate donor screening. See Michele Goodwin, supra note 2, at 7ff and 155; Melanie Mader, supra note 4, at $273 \mathrm{ff}$. 
reduce the need for organs by improving population health (demand side). Rising levels of obesity, high blood pressure, and diabetes contribute to the demand for kidneys. Public health initiatives designed to induce healthier lifestyles and aimed at preventing end-stage organ failure are thus crucial. In this paper, however, we focus on the regulatory tool of incentives to encourage individuals to express their consent to donate. We suggest here that incentives supplement other ways of aligning organ demand and supply.

State incentives adhere to a system of rewarded donation, situated between altruism and pure profit. This alternative approach overthrows the traditional and unconvincing gift versus market dichotomy. Through incentives, the state honors the act of solidarity of the donor in favor of the recipient and society. A reward for donors or their relatives is thus best viewed as a facilitator for altruism, rather than a replacement. Public policy incentives support individual choice and promote communitarian interests. The paradigm of donation as a generous and solidary act is preserved, as no systemic change is forced upon current organ procurement practices. Moreover, state incentives take into account the crucial attributes of reciprocity and mixed motives underlying organ donation.

The key criterion for the regulatory design of incentives is the adequate and proportionate expression of appreciation and gratitude by the state for the act of organ donation. Conceived as such, incentives promote individuals' willingness to donate, without violating the prohibition of organ sales. They maintain a strong normative position against private commercial transactions involving organs. With adequate safeguards in place, there are no decisive objections to using incentives in a public policy to promote organ donation.

State incentives have to ensure respect, benefit, and protection from harm for both the donor (and his relatives) and the recipient. Certain incentives are thus preferable from a legal and ethical point of view: first, incentives for post mortem donation, since they do not imply harming the physical integrity of a healthy individual and do not involve risks for the donor; second, non-financial incentives, as they better guarantee the quality of the donor's consent; finally, for the same reasons, indirect financial incentives as opposed to direct financial ones. Considering the various incentives discussed here, this leaves us with the following result.

Direct financial incentives (futures market, regulated organ market) assign a monetary value to organs and, therefore, violate the prohibition of organ sales, a legal principle widely enacted in international and domestic law. There is a clear normative tendency toward avoiding the full commercialization of body material, in particular organs. Introducing direct financial incentives implies recognizing a property right in organs and abandoning the prohibition of organ sales. A public policy based on such incentives has thus to be ruled out. The effectiveness of indirect financial incentives for living donation (reduction of health insurance premiums, tax credits) seems arguable. Today living donation remains an act that in most cases occurs within close familial or affectionate relationships. The introduction of incentives would probably not have a significant impact in this regard.

However, legally and ethically acceptable regulatory tools exist to ease the organ shortage and the suffering of patients in need. The incentive of allocation priority for registered donors, in particular, communicates a compelling and straightforward 
message: give and receive. It relates to the concepts of solidarity and reciprocity among the members of a given society. Reciprocity is a key element in sociological gift exchange theory. Combined with a public awareness campaign focusing on civilization diseases and the risk of needing a kidney at some point in one's life, this incentive is a convincing tool to increase the number of individuals who manifest their willingness to donate organs after death. Israel has introduced an allocation priority incentive in April 2012. The first empirical results published since its implementation are very positive. The Israeli system has to be carefully monitored to follow its effectiveness in expanding the number of available organs over time. Eventually, the legitimacy of any incentive depends on its ability to boost the number of organs donated.

Indirect financial incentives (tax credits, reduction of health insurance premiums) are an appealing means to increase the number of individuals who express consent to post mortem organ donation during their lifetime. Indirect financial incentives can also address close relatives after a potential donor's death (participation in funeral expenses). Although such incentives involve spending public funds, they most likely do not cause an overall increment in public expenditure. As they increase the number of organs transplanted, costs elsewhere in the health care system, dialysis costs most importantly, can be reduced. Having more organs available also allows for decreased spending within the social security system, as transplanted patients usually return to the workforce.

State incentives constitute a convincing remedy to address the organ shortage and its serious consequences. They offer a promising solution to improve the situation of patients in need. In an attempt to re-equilibrate the gift relationship, the public policy suggested here acknowledges a generous act, takes into account the diverse motives underlying organ donation, and combines altruism with an emphasis on reciprocity and solidarity. Legal and ethical concerns raised by the introduction of incentives can be accommodated through adequate regulatory design. The example of Israel's legal framework might lead the way for other states to follow, as Israel is in the unique position to have successfully implemented such an incentive.

\section{ACKNOWLEDGEMENTS}

The author thanks the Swiss National Science Foundation, the Faculty of Law at McGill University, and the Edmond J. Safra Center for Ethics at Tel Aviv University for their funding and institutional support. She thanks the audiences at McGill University; Tel Aviv University; $4^{\text {th }}$ Congress on Ethical, Legal and Psychological Aspects of Transplantation; $10^{\text {th }}$ UNESCO World Conference on Bioethics, Medical Ethics and Health Law; various Swiss University Hospitals; and the Swiss Federal Office of Justice for comments on earlier drafts. She also thanks two anonymous reviewers for helpful comments. 